Exploring Old and New Benzene Formation Pathways in Low-Pressure Premixed Flames of Aliphatic Fuels

Christopher J. Pope and James A. Miller

Combustion Research Facility

Sandia National Laboratories

Livermore, CA 94551-0969, USA

The aubmitted manuscript has been authored by a contractor of the United States Government under contract. Accordingly the United States Government retains a non-exclusive, ernment retains a non-exclusive, produce the published form of this contribution, or allow others to do so, for United States Government purposes.

Submitted to the Twenty-Eighth Symposium (International) on Combustion, Edinburgh, Scotland, July 30 - August 4, 2000.

Corresponding author:

\author{
Dr. Christopher J. Pope \\ Mail Stop 9055 \\ Sandia National Laboratories \\ Livermore, CA 94550-0969 \\ U.S.A. \\ Fax: (925) 294-2276 \\ E-mail: jamille@ca.sandia.gov
}

RECEIVED

FFR 232000

OSTI

Colloquium: Reaction Kinetics of Combustion or Soot, PAH and Air Toxics

Total word count:

text + references $\quad 3524$ words

five figures $\quad 1000$ words

four tables $\quad 800$ words

total 5324 words

Requesting an oral presentation 


\section{DISCLAIMER}

This report was prepared as an account of work sponsored by an agency of the United States Government. Neither the United States Government nor any agency thereof, nor any of their employees, make any warranty, express or implied, or assumes any legal liability or responsibility for the accuracy, completeness, or usefulness of any information, apparatus, product, or process disclosed, or represents that its use would not infringe privately owned rights. Reference herein to any specific commercial product, process, or service by trade name, trademark, manufacturer, or otherwise does not necessarily constitute or imply its endorsement, recommendation, or favoring by the United States Government or any agency thereof. The views and opinions of authors expressed herein do not necessarily state or reflect those of the United States Government or any agency thereof. 


\section{DISCLAIMER}

Portions of this document may be illegible in electronic image products. Images are produced from the best available original document. 


\title{
Exploring Old and New Benzene Formation Pathways \\ in Low-Pressure Premixed Flames of Aliphatic Fuels
}

\author{
Christopher J. Pope and James A. Miller \\ Combustion Research Facility \\ Sandia National Laboratories \\ Livermore, CA 94551-0969, USA
}

\begin{abstract}
A modeling study of benzene and phenyl radical formation is performed for three low-pressure premixed laminar flat flames having an unsaturated $\mathrm{C}_{2}$ or $\mathrm{C}_{3}$ hydrocarbon fuel (acetylene, ethylene, and propene). Predictions using three published detailed elementary-step chemical kinetics mechanisms are tested against MBMS species profile data for all three flames. The differences between the three mechanisms predictive capabilities are explored, with an emphasis on benzene formation pathways. A new chemical kinetics mechanism is created combining features of all three published mechanisms. Included in the mechanism are several novel benzene formation reactions involving combinations of radicals such as $\mathrm{C}_{2} \mathrm{H}+\mathrm{C}_{4} \mathrm{H}_{5}, \mathrm{C}_{2} \mathrm{H}_{3}+\mathrm{C}_{4} \mathrm{H}_{3}$, and $\mathrm{C}_{5} \mathrm{H}_{3}+\mathrm{CH}_{3}$. Reactions forming fulvene (a benzene isomer) are included, such as $\mathrm{C}_{3} \mathrm{H}_{3}+\mathrm{C}_{3} \mathrm{H}_{5}$, as well as fulvene-to-benzene reactions.

Predictions using the new mechanism show virtually all of the benzene and phenyl radical to be formed by reactions of either $\mathrm{C}_{3} \mathrm{H}_{3}+\mathrm{C}_{3} \mathrm{H}_{3}$ or $\mathrm{C}_{3} \mathrm{H}_{3}+\mathrm{C}_{3} \mathrm{H}_{5}$, with the relative importance being strongly dependent upon the fuel. $\mathrm{C}_{5} \mathrm{H}_{3}+\mathrm{CH}_{3}$ plays a minor role in fulvene formation in the acetylene flame. The $\mathrm{C}_{2} \mathrm{H}_{\mathrm{x}}+\mathrm{C}_{4} \mathrm{H}_{\mathrm{x}}$ reactions do not contribute noticeably to benzene or phenyl radical formation in these flames, sometimes being a major decomposition channel for either fulvene or phenyl radical. The formation pathways for $\mathrm{C}_{3} \mathrm{H}_{3}$ and $\mathrm{C}_{3} \mathrm{H}_{5}$ are delineated for the three flames; while the key reactions differ from flame to flame, ${ }^{1} \mathrm{CH}_{2}+\mathrm{C}_{2} \mathrm{H}_{2} \Leftrightarrow \mathrm{C}_{3} \mathrm{H}_{3}+\mathrm{H}$ is important for all three flames.
\end{abstract}




\section{INTRODUCTION}

A molecular-level understanding of combustion chemistry is essential for controlling the products of molecular-weight growth, which can lead to the formation of polycyclic aromatic hydrocarbons (PAH), many of which are known mutagens and/or carcinogens. The PAH themselves are likely precursors of soot particles in flames. For flames of aliphatic fuels, all of the aromatic rings, including the first, need to be formed by combination of smaller hydrocarbon fragments, thus providing motivation for understanding benzene formation in combustion.

Considering the level of interest in benzene formation, the lack of consensus on what the major reaction pathways are might be surprising to the casual observer. Thorough reviews of all but the most recent work are provided by Westmoreland, et al. [1] and Melius et al. [2]. Two broad types of ring-forming reactions appear: acetylene $\left(\mathrm{C}_{2} \mathrm{H}_{2}\right)$ addition to a $\mathrm{C}_{4}$ vinyl radical, with subsequent cyclization, i.e., reactions \#296 [3] and \#297 [4] in Table 1; (2) combination of resonantly stabilized free radicals (RSFRs), with subsequent rearrangement and ring formation, e.g., reaction \#412, propargyl $(\mathrm{H} 2 \mathrm{CCCH})$ radical recombination, $2 \mathrm{C}_{3} \mathrm{H}_{3}(\mathrm{H} 2 \mathrm{CCCH}) \Leftrightarrow \mathrm{C}_{6} \mathrm{H}_{5}$ (phenyl) $+\mathrm{H}[2,5]$.

In the acetylene-addition reactions, one reactant $\left(\mathrm{C}_{2} \mathrm{H}_{2}\right)$ is a major product of fuelrich combustion, present in high concentrations, and the adduct does not require intramolecular rearrangments prior to cyclization. However, both $n-\mathrm{C}_{4} \mathrm{H}_{3}(\mathrm{HCCHCCH})$ and $\mathrm{n}-\mathrm{C}_{4} \mathrm{H}_{5}(\mathrm{CH} 2 \mathrm{CHCHCH})$ have more stable isomers -- $\mathrm{i}-\mathrm{C}_{4} \mathrm{H}_{3}(\mathrm{H} 2 \mathrm{CCCCH})$ and and $\mathrm{i}-$ $\mathrm{C}_{4} \mathrm{H}_{5}(\mathrm{CH} 2 \mathrm{CHCCH} 2)$ [5] -- into which they can readily be converted, greatly diminishing the amount of the $n-C_{4} H_{3}$ and $n-C_{4} H_{5}$ available. While $\# 296$ and $\# 297$ are strongly 
exothermic, they also have large decreases in entropy, becoming less favored at higher temperatures. Furthermore, \#297 has a net decrease in number of moles, causing it to be less favored at lower pressures.

Relatively high concentrations of $\mathrm{C}_{3} \mathrm{H}_{3}$ are also seen in flames, due to the resonance-enhanced stability of propargyl. In low-pressure acetylene [1], 1,3-butadiene $\left(\mathrm{C}_{4} \mathrm{H}_{6}\right)$ [4], and benzene [18] flames, peak mole fractions of $\mathrm{C}_{3} \mathrm{H}_{3}$ near $10^{-3}$ were observed. Recombination of propargyl radical also has no barrier to forming a ringcontaining C6 species, whether it be fulvene, benzene, or phenyl+H $[2,5,19]$; R3 can therefore become a direct aromatic ring formation route, especially at low pressures. However, reaction $\# 412$ has a crossover temperature (above which $\Delta \mathrm{G}>0$ ) of $1729 \mathrm{~K}$, and is much less thermodynamically favored than $\# 297$, with a crossover temperature of 2218 $\mathrm{K}$.

Other pathways to benzene have been proposed. Lindstedt and Skevis [20] consider $\mathrm{C}_{2} \mathrm{H}_{3}+\mathrm{C}_{4} \mathrm{H}_{4}(\mathrm{CH} 2 \mathrm{CHCCH}) \Leftrightarrow \mathrm{C}_{6} \mathrm{H}_{6}($ benzene $)+\mathrm{H}$ and $\mathrm{C}_{2} \mathrm{H}_{3}+\mathrm{C}_{4} \mathrm{H}_{6}(\mathrm{CH} 2 \mathrm{CHCHCH} 2) \Leftrightarrow \mathrm{C}_{6} \mathrm{H}_{8}(1,4-$ cyclohexadiene $)+\mathrm{H}$, with the $\mathrm{C}_{6} \mathrm{H}_{8}$ decomposing to benzene and $\mathrm{H}_{2}$. Marinov et al. [14] propose a combination of two $\mathrm{C}_{3}$ RSFRs, propargyl and allyl (\#416). Moskaleva et al. [21] consider methyl+cyclopentadienyl (also a RSFR), forming methylcyclopentadiene, which forms fulvene, then benzene. Mebel et al. [17] calculate the potential energy surface of $\mathrm{C}_{6} \mathrm{H}_{6}$ (benzene) $\Leftrightarrow \mathrm{C}_{5} \mathrm{H}_{3}+\mathrm{CH}_{3}$ reactions. The reverse reactions can also be possible benzene formation pathways (\#522-527) from either of the two most stable forms of $\mathrm{C}_{5} \mathrm{H}_{3}, \mathrm{H} 2 \mathrm{CCCCCH}$ (here called $\left.\mathrm{i}-\mathrm{C}_{5} \mathrm{H}_{3}\right)$ and $\mathrm{HCCCHCCH}\left(\mathrm{n}-\mathrm{C}_{5} \mathrm{H}_{3}\right)$. Walch [22] 
calculates the potential energy surface of both $\# 297$ and the reaction of $\mathrm{i}-\mathrm{C}_{4} \mathrm{H}_{3}$ with acetylene.

There are not infinitely many benzene formation reactions. Considering only bimolecular reactions, the two reactants should collectively contain precisely six carbon atoms and roughly six hydrogen atoms (for the above examples, five to nine hydrogen atoms). An ultimate goal would be to determine which of the conceivable benzene formation pathways are important. The answer would be complex, probably depending on the fuel and on the reactor conditions, even for the rather restricted case of lowpressure premixed flames of aliphatic fuels.

\section{$\underline{\text { APPROACH }}$}

To assess the possible importance of various benzene formation pathways, we performed a modeling study on three sets of flame data. The flames selected are all fuelrich low-pressure premixed laminar flat flames with an unsaturated $C_{2}$ or $C_{3}$ hydrocarbon as a fuel $\left(\mathrm{C}_{2} \mathrm{H}_{2}\right.$-- flame $\mathrm{F} 1$ [23], $\mathrm{C}_{2} \mathrm{H}_{4}--\mathrm{F} 2$ [24], $\mathrm{C}_{3} \mathrm{H}_{6}$ propene -- $\mathrm{F} 3$ [25]), with measured temperature profiles and species concentration profiles (including benzene) measured by molecular beam mass spectrometry (MBMS). See Table 2 for flame properties. Modeling calculations employed the CHEMKIN programs [26-30]. Full multicomponent diffusion, including thermal diffusion, was calculated. The catalytic boundary condition for $\mathrm{H}$-atom recombination at the burner surface was also included. Experimental temperature profiles were used as input, in lieu of solving the energy equation. 
Three different chemical kinetics mechanisms were tested. The first (M1) is the mechanism of Pauwels et al. [6], derived from Miller and Melius [5], plus 47 reactions describing the chemistry of propene and of the three $\mathrm{C}_{3} \mathrm{H}_{5}$ isomers, from Marinov et al. $[11,12]$, which allows modeling of the propene flame (F3). The second mechanism (M2) is from Richter et al. [16], based on Zhang and McKinnon [31], with extensive PAH formation chemistry at low-pressure (20 Torr). To afford a more complete comparison, the reaction ${ }^{1} \mathrm{CH}_{2}+\mathrm{C}_{2} \mathrm{H}_{2} \Leftrightarrow \mathrm{H} 2 \mathrm{CCCH}+\mathrm{H}$ was added to M2. The third mechanism (M3) is

from Marinov et al. [11,12,14]. M3 builds on the Miller and Melius [5] chemistry by including additional reactions of RSFRs and PAH formation reactions at atmosphericpressure. While many other chemical kinetics mechanisms are available in the literature, the three chosen here provide a reasonable basis for comparison, showing areas in which M1 can be improved.

\section{MODELING RESULTS}

All three mechanisms do well at predicting the decay of fuel and $\mathrm{O}_{2}$ in the three flames. Table 3 lists the experimental and the predicted peak mole fractions for the three flames. The predictions also include those from an extensively modified and expanded version of M1, called M1a. The key changes made in forming M1a, and the modeling results using M1a, are discussed below.

All three mechanisms predict both the peak concentration and the shape of the $\mathrm{C}_{2} \mathrm{H}_{2}$ profiles quite well in all three flames. $M 3$ over-predicts peak $\mathrm{C}_{6} \mathrm{H}_{6}$ mole fractions for all three flames. Many of the pressure-dependent reactions in M3 have rate coefficients that are fit for atmospheric pressure, so M3 over-predicts molecular-weight 
growth in such reactions as $\mathrm{C}_{2} \mathrm{H}_{3}+\mathrm{CH}_{3} \Leftrightarrow \mathrm{C}_{3} \mathrm{H}_{6}$, hence the over-prediction of $\mathrm{C}_{3} \mathrm{H}_{6}$ in $\mathrm{F}$, $\mathrm{C}_{4} \mathrm{H}_{8}$ in $\mathrm{F} 2$ and $\mathrm{F} 3$, and $\mathrm{C}_{4} \mathrm{H}_{3}$ and $\mathrm{C}_{4} \mathrm{H}_{5}$ in all three flames. However, $\mathrm{C}_{6} \mathrm{H}_{5}$ concentrations are under-predicted.

Peak $\mathrm{C}_{6} \mathrm{H}_{6}$ mole fraction predictions from $\mathrm{M} 2$ are within $25 \%$ for $\mathrm{F} 1$, a factor of 10 low for F2, and roughly 100 times too low for F3. M2 does not include the propargyl recombination reaction (R3), which most likely explains the $\mathrm{C}_{6} \mathrm{H}_{6}$ shortfall and $\mathrm{C}_{3} \mathrm{H}_{3}$ over-prediction for the three flames. In $\mathrm{F} 1$, formation of $\mathrm{C}_{6} \mathrm{H}_{6}$ is by $\mathrm{C}_{3} \mathrm{H}_{3}+\mathrm{C}_{3} \mathrm{H}_{4}$ (allene) $\Leftrightarrow \mathrm{C}_{6} \mathrm{H}_{6}+\mathrm{H}$, yet $\mathrm{C}_{3} \mathrm{H}_{4}$ is also over-predicted.

The predicted peak $\mathrm{C}_{6} \mathrm{H}_{6}$ mole fractions using $\mathrm{M} 1$ range from $30 \%$ to $50 \%$ of the data. Peak $\mathrm{C}_{3} \mathrm{H}_{3}$ is roughly 2.5 times the data for $\mathrm{F} 1,1.6$ times for $\mathrm{F} 2$, and 1.3 times for F3, although for $\mathrm{F} 1$ and $\mathrm{F} 2$ the $\mathrm{M} 1$ predictions come closest to the data. Peak $\mathrm{C}_{4} \mathrm{H}_{3}$ mole fractions are higher than the data for all 3 flames. Predicted $\mathrm{C}_{4} \mathrm{H}_{5}$ peaks are 30 times low for $\mathrm{F} 1,8$ times high for $\mathrm{F} 2$, and $15 \%$ low for $\mathrm{F} 3 . \mathrm{C}_{6} \mathrm{H}_{5}$ predictions are roughly 8 times low for $\mathrm{F} 2$, and $40 \%$ high for $\mathrm{F} 3$, following the same trend as the $\mathrm{M} 2$ predictions.

\section{EXPANDED BENZENE FORMATION CHEMISTRY}

Building on the mechanism M1 [5,6], a significantly expanded mechanism (M1a) was created, containing 91 species and 527 reactions. ${ }^{*}$ Beyond the $\mathrm{C}_{3} \mathrm{H}_{5}$ and $\mathrm{C}_{3} \mathrm{H}_{6}$ species and reactions, two other large additions were made using reactions from either M2 [16] or M3 [11,12]. The chemistry of the five new $\mathrm{C}_{5}$ species $\left(\mathrm{C}_{5} \mathrm{H}_{5} \mathrm{O}, \mathrm{C}_{5} \mathrm{H}_{6}\right.$, linear $\mathrm{C}_{5} \mathrm{H}_{5}, \mathrm{C}_{5} \mathrm{H}_{4} \mathrm{O}$, and $\left.\mathrm{C}_{5} \mathrm{H}_{4} \mathrm{OH}\right)$ was added, making the benzene oxidation chemistry more complete. The chemistry of seventeen species from $\mathrm{C}_{6} \mathrm{H}_{7}$ (cyclohexadienyl) to $\mathrm{C}_{10} \mathrm{H}_{8}$

\footnotetext{
*The mechanism is available by contacting the authors at cjpope@sandia.gov or jamille@ca.sandia.gov.
} 
(naphthalene) was added from M2, since M2 was developed to model a 20-Torr flame, although many of the reactions were contained in both M2 and M3.

In addition to the sweeping changes mentioned above, several individual reactions were added, and several of the rate coefficients for reactions already included were modified. Rate coefficients for reactions \#296 and \#297 are from Wang and Frenklach [10]. As an upper bound for these rates, the 20 Torr fits for $\# 297$ of all four product channels [10] were summed and used as the rate for $\mathrm{C}_{2} \mathrm{H}_{2}+\mathrm{n}-\mathrm{C}_{4} \mathrm{H}_{3}(\mathrm{HCCHCCH}) \Leftrightarrow \mathrm{C}_{6} \mathrm{H}_{5}$ (phenyl). Similarly, the sum of the four product channels for $\# 296$ for 0-90 Torr [10] is for the product channel $\mathrm{C}_{6} \mathrm{H}_{6}($ benzene $)+H$. The resulting sums for \#296 and \#297 were fit into the 3-parameter Arrhenius form. The barrier height used [10] for \#297 was $3.1 \mathrm{kcal} / \mathrm{mol}$; the barrier calculated by Walch [22] is $8.3 \mathrm{kcal} / \mathrm{mol}$, close to the AM1 barrier height [10]. Accordingly, the activation energy for \#297 fitted above was increased by $5.2 \mathrm{kcal} / \mathrm{mol}$. The newly fitted activation energy for \#296 was increased by the same amount. The rate for $\mathrm{C}_{6} \mathrm{H}_{5}+\mathrm{C}_{2} \mathrm{H}_{2} \Leftrightarrow \mathrm{C}_{6} \mathrm{H}_{5} \mathrm{C}_{2} \mathrm{H}+\mathrm{H}$ is taken from Yu et al. [15], by fitting the sum of the rates for all product channels.

The overall rate for $\mathrm{C}_{2} \mathrm{H}_{3}+\mathrm{C}_{2} \mathrm{H}_{3}$ was changed to $9.0 * 10^{13} \mathrm{~cm}^{3} / \mathrm{mol}-\mathrm{s}[7,8]$. Consistent with the observation of a $\mathrm{C}_{3} \mathrm{H}_{3}+\mathrm{CH}_{3}$ product channel [9], the branching ratio was set to $10 \% \quad \mathrm{i}-\mathrm{C}_{4} \mathrm{H}_{5}+\mathrm{H}, \quad 20 \% \quad \mathrm{C}_{3} \mathrm{H}_{3}+\mathrm{CH}_{3}, \quad 70 \% \quad \mathrm{C}_{2} \mathrm{H}_{2}+\mathrm{C}_{2} \mathrm{H}_{4}$. Rates for $\mathrm{C}_{2} \mathrm{H}_{3}+\mathrm{CH}_{3} \Leftrightarrow \mathrm{C}_{3} \mathrm{H}_{6}$ or $\mathrm{C}_{3} \mathrm{H}_{5}+\mathrm{H}$ are from Tsang and Hampson's [13] 20 Torr results. $\mathrm{C}_{3} \mathrm{H}$ chemistry (\#406-408) was added, with thermochemical properties from Guadagnini et al. [32]. Allyl-propargyl recombination (\#416) in M3 forms much of the benzene in F2 and F3, so this reaction is added, although the authors [14] give the rate coefficient as an 
upper bound at $1 \mathrm{~atm}$. Also added are two reactions for converting fulvene into benzene (\#415,\#418). (See Table 1 for reactions and rate coefficients.)

\section{RADICAL-RADICAL RECOMBINATION REACTIONS FOR $\mathrm{C}_{6} \underline{\mathrm{H}}_{6}$ FORMATION}

Several chemically activated radical-radical combinations are proposed as possible benzene-forming reactions in M1a (\#506-527). For propargyl-propargyl recombination, not only the initial adduct but also several of the rearrangement products/intermediates are aliphatic $\mathrm{C}_{6} \mathrm{H}_{6}$ species [2,5,19]; many other radical-radical

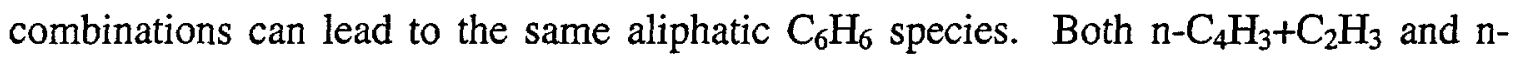
$\mathrm{C}_{4} \mathrm{H}_{5}+\mathrm{C}_{2} \mathrm{H}$ can combine to form $\mathrm{CH} 2 \mathrm{CHCHCHCCH}$. $\mathrm{CH} 3 \mathrm{CHCCHCCH}$, formed by $\mathrm{n}$ $\mathrm{C}_{5} \mathrm{H}_{3}+\mathrm{CH}_{3}$, which can undergo a hydrogen shift to form $\mathrm{CH} 2 \mathrm{CHCHCHCCH}$. Combination of $\mathrm{i}-\mathrm{C}_{4} \mathrm{H}_{3}+\mathrm{C}_{2} \mathrm{H}_{3}$ or $\mathrm{i}-\mathrm{C}_{4} \mathrm{H}_{5}+\mathrm{C}_{2} \mathrm{H}$ can form $\mathrm{CH} 2 \mathrm{C}(\mathrm{CCH}) \mathrm{CHCH} 2$. i$\mathrm{C}_{4} \mathrm{H}_{5}+\mathrm{C}_{2} \mathrm{H}$ also forms $\mathrm{CH} 2 \mathrm{CCHCH} 2 \mathrm{CCH}$, which also directly forms from $\mathrm{C}_{3} \mathrm{H}_{3}+\mathrm{C}_{3} \mathrm{H}_{3}$. $\mathrm{CH} 3 \mathrm{CHCCCCH} 2$ from $\mathrm{i}-\mathrm{C}_{5} \mathrm{H}_{3}+\mathrm{CH}_{3}$ can undergo a hydrogen shift to form $\mathrm{CH} 2 \mathrm{CCCHCHCH}$ 2. $\mathrm{CH} 2 \mathrm{CCCHCHCH} 2$ is also a product of $\mathrm{i}-\mathrm{C}_{4} \mathrm{H}_{3}+\mathrm{C}_{2} \mathrm{H}_{3}$, converting via a hydrogen shift to $\mathrm{CH} 2 \mathrm{CCHCHCCH}$, another direct propargyl-propargyl recombination product. Once any of these aliphatic $\mathrm{C}_{6} \mathrm{H}_{6}$ adducts is formed, the chemistry leading to either fulvene, benzene, or phenyl+H is described by Miller and coworkers $[2,5,19]$. The overall rate for adduct formation and subsequent reaction for each of these new reactions is estimated to be $2 * 10^{13} \mathrm{~cm}^{3} / \mathrm{mol}-\mathrm{s}$. H-abstraction reactions from these pairs of radicals are also included in the new mechanism, as are reactions interrelating $\mathrm{C}_{5} \mathrm{H}_{2}, \mathrm{i}-\mathrm{C}_{5} \mathrm{H}_{3}$, and $\mathrm{n}-\mathrm{C}_{5} \mathrm{H}_{3}(\# 409-411)$. 
All of these new reactions are written in the exothermic direction. Standard heats of formation for the above $\mathrm{C}_{6} \mathrm{H}_{6}$ species and combinations of molecules with combined empirical formula of $\mathrm{C}_{6} \mathrm{H}_{6}$ are given in Table 4. The heat of formation used for propargyl radical is $86.0 \mathrm{kcal} / \mathrm{mol}[33,34]$, and the standard entropy is $59.9 \mathrm{cal} / \mathrm{mol}-\mathrm{K}$ [34]; the earlier values used were $83.0 \mathrm{kcal} / \mathrm{mol}$ and $61.4 \mathrm{cal} / \mathrm{mol}-\mathrm{K}$. The less stable propargyl radical results in slightly lower predicted $\mathrm{C}_{3} \mathrm{H}_{3}$ mole fractions, and therefore a slightly diminished role of $\mathrm{C}_{3} \mathrm{H}_{3}+\mathrm{C}_{3} \mathrm{H}_{3}$ in benzene formation. Predicted peak mole fractions of $\mathrm{C}_{4} \mathrm{H}_{3}$ and $\mathrm{C}_{4} \mathrm{H}_{5}$ also increase by at least a factor of 3 in all three flames. The total rate for the propargyl+propargyl reaction is kept at $1 * 10^{13} \mathrm{~cm}^{3} / \mathrm{mol}-\mathrm{s}$; measured values are 2.4$7.2 * 10^{13} \mathrm{~cm}^{3} / \mathrm{mol}-\mathrm{s}$ [35-38]. Master equation calculations [39] show that at conditions of the flames considered here benzene is not formed directly. Accordingly, the branching ratio used has the products being split nearly evenly between fulvene and phenyl $+\mathrm{H}$, with i- $\mathrm{C}_{5} \mathrm{H}_{3}+\mathrm{CH}_{3}$ being a minor pathway since it is slightly exothermic (\#412-414). (Not enough confidence was placed in the $2.1 \mathrm{kcal} / \mathrm{mol}$ exothermicity of the $\mathrm{n}_{-} \mathrm{C}_{5} \mathrm{H}_{3}+\mathrm{CH}_{3}$ product channel to believe that it would be significant.)

\section{DISCUSSION OF RESULTS FROM IMPROVED MECHANISM}

Predictions using M1 and M1a are compared against data in Figure 1 for $\mathrm{C}_{6} \mathrm{H}_{6}$. Benzene is the only $\mathrm{C}_{6} \mathrm{H}_{6}$ species in M1, while M1a also includes fulvene. For F1 (Fig. 1a), M1a greatly improves $\mathrm{C}_{6} \mathrm{H}_{6}$ predictions. Little fulvene is predicted. An improvement is also seen for F2 (Fig. 1b), with an appreciable amount of fulvene predicted early in the flame. M1a overpredicts $\mathrm{C}_{6} \mathrm{H}_{6}$ concentrations in F3 (Fig. 1c), with fulvene being dominant early in the flame. 
The major reaction pathways leading to phenyl, fulvene, and benzene are shown in Figure 2. For all three flames, the propargyl-propargyl reaction (\#412-414) plays a major role. The propargyl-allyl reaction (\#416) contributes a moderate amount in F2, and forms most of the benzene in F3; in F1, this reaction actually is a major fulvene decomposition pathway. Use of the 1-atm rate coefficient for this reaction is most likely responsible for the over-prediction of $\mathrm{C}_{6} \mathrm{H}_{6}$ in F3. The $\mathrm{C}_{2} \mathrm{H}_{2}+\mathrm{n}-\mathrm{C}_{4} \mathrm{H}_{3}$ reaction (\#297) is almost entirely a phenyl decomposition pathway in F2 and F3; in F1 there is a slight amount of phenyl production followed by phenyl decomposition, but the reaction is of negligible importance. The $\mathrm{C}_{2} \mathrm{H}_{2}+\mathrm{n}-\mathrm{C}_{4} \mathrm{H}_{5}$ reaction (\#296) has no discernible effect for any of the flames studied.

Of the new radical-radical reactions added (\#506-527), only the $\mathrm{i}-\mathrm{C}_{5} \mathrm{H}_{3}+\mathrm{CH}_{3}$ reaction appears as a substantial formation reaction (with a minor contribution from n- $\mathrm{C}_{5} \mathrm{H}_{3}+\mathrm{CH}_{3}$ ), and then only in F1. The relation of the $\mathrm{C}_{5} \mathrm{H}_{2}$ and $\mathrm{C}_{5} \mathrm{H}_{3}$ species with the polyacetylene pool (reactions \#267, 309-311, 409-411) leads to more of these species being formed in F1 (q.v. Table 3). Unfortunately, there are no data for testing these predicted concentrations. For $\mathrm{F} 2$ and $\mathrm{F} 3$, the major role of the $\mathrm{i}-\mathrm{C}_{5} \mathrm{H}_{3}+\mathrm{CH}_{3}$ reactions appears to be as another pathway for converting fulvene to benzene. Whether this indeed happens in reality is questionable; however, further investigation of the possible role of these $\mathrm{C}_{5} \mathrm{H}_{3}$ species is indicated. The only other new reactions appearing in Fig. 2 involve i- $\mathrm{C}_{4} \mathrm{H}_{3}+\mathrm{C}_{2} \mathrm{H}_{3}$ (\#513,\#514) as decomposition products of either fulvene or phenyl+H.

No $\mathrm{C}_{2}+\mathrm{C}_{4}$ reaction in the mechanism is predicted to lead to benzene formation in any of these flames -- only reactions involving $C_{3}$ radicals are important. Figure 3 shows the major predicted pathways for $\mathrm{C}_{3}$ radical formation from the fuel for the three flames. 
For $\mathrm{F} 3$, the main source of $\mathrm{C}_{3} \mathrm{H}_{3}$ and $\mathrm{C}_{3} \mathrm{H}_{5}$ radicals is by successive $\mathrm{H}$-abstractions from the fuel. While ${ }^{1} \mathrm{CH}_{2}+\mathrm{C}_{2} \mathrm{H}_{2} \Leftrightarrow \mathrm{H} 2 \mathrm{CCCH}+\mathrm{H}$ and the reactions leading to it are the dominant source of $\mathrm{C}_{3}$ radicals in $\mathrm{F} 1$ and $\mathrm{F} 2$, it appears as a secondary pathway in $\mathrm{F} 3$, with the fuel decomposing to ethylene or vinyl radical, forming acetylene by $\mathrm{H}$ abstraction. In $\mathrm{F} 2, \mathrm{C}_{2} \mathrm{H}_{4}$ and $\mathrm{C}_{2} \mathrm{H}_{3}$ combine with $\mathrm{C}_{1}$ radicals to form allyl radical. In $\mathrm{F} 1$, the fuel combines with methyl radical to give propyne+H, with the propyne then forming propargyl.

Therefore, for the low-pressure flames studied here, only combinations of $\mathrm{C}_{3}$ radicals lead to production of benzene or phenyl. However, it is conceivable that there would be fuels or flame conditions that would favor the $\mathrm{C}_{2}+\mathrm{C}_{4}$ pathways. For example, $\mathrm{C}_{2} \mathrm{H}_{2}+\mathrm{n}-\mathrm{C}_{4} \mathrm{H}_{3} \Leftrightarrow \mathrm{C}_{6} \mathrm{H}_{5}$ (\#297) is the only one of the important molecular-weight growth reactions involving phenyl (\#297, 412, 417, 483, 487, 501, 507, 514, 523, 526) to have a net mole change. The rates of bimolecular reactions, expressed as $\mathrm{mol} \mathrm{C}_{6} \mathrm{H}_{5} / \mathrm{g}$ gas $/ \mathrm{sec}$ (the molar rate divided by the gas density), would increase linearly with pressure, while those of unimolecular rates would remain constant, all else being equal. The relative importance of \#297 to the other molecular-weight growth reactions at higher pressures can then be approximated by looking only at the forward rate of \#297. However, the peak forward rate of \#297 is $2.4 \%$ of the peak of the sum of the net rates of all the other molecular-weight growth reactions for F1, and less than $1 \%$ for $F 2$ and F3. Therefore, increased pressure alone would decrease the importance of $\# 297$ as a phenyl decomposition channel, but would not make \#297 an important phenyl production route. This is more noteworthy since $\mathrm{C}_{4} \mathrm{H}_{3}$ is overpredicted in all three flames, and since the $\mathrm{n}-\mathrm{C}_{4} \mathrm{H}_{3} / \mathrm{i}-\mathrm{C}_{4} \mathrm{H}_{3}$ and $\mathrm{n}-\mathrm{C}_{4} \mathrm{H}_{5} / \mathrm{i}-\mathrm{C}_{4} \mathrm{H}_{5}$ ratios are at least an order of magnitude above 
partial equilibrium for all positions in all three flames. Secondary effects of pressure, such as increasing the rates of $\mathrm{C}_{4}$-radical forming reactions, cannot be ruled out.

In summary, for the three flames considered, the only major formation pathways for benzene or phenyl are the result of combination of $\mathrm{C}_{3}$ radicals. The $\mathrm{C}_{2} \mathrm{H}_{2}+\mathrm{C}_{4}$ radical pathways were tested thoroughly and found to be at best unimportant in single-ring aromatic formation. The relative importance of different benzene/phenyl/fulvene reaction pathways is fuel-dependent, as are the major pathways for formation of the $C_{3}$ radicals. No claims to generality can be made for other fuels, flow systems, or pressures. However, in modeling of low-pressure $\mathrm{C}_{2} \mathrm{H}_{2}$ flames [40] and atmospheric-pressure $\mathrm{C}_{2} \mathrm{H}_{4}$ flames [40-42], recombination of propargyl radical was found to be an important contributor to benzene formation.

The new pathways proposed to $\mathrm{C}_{6} \mathrm{H}_{6}$ are pertinent to the overall role of RSFRs in benzene formation, since the aliphatic $\mathrm{C}_{6} \mathrm{H}_{6}$ adducts formed are the same as for the $\mathrm{C}_{3} \mathrm{H}_{3}+\mathrm{C}_{3} \mathrm{H}_{3}$ reaction. The $\mathrm{C}_{5} \mathrm{H}_{3}+\mathrm{CH}_{3}$ reactions played a role in the predicted benzene/phenyl formation chemistry, perhaps due to their only being $-32-38 \mathrm{kcal} / \mathrm{mol}$ higher in energy than phenyl+H. However, due to concentration effects and net increase in number of moles, even the $\mathrm{C}_{2} \mathrm{H}_{2}+\mathrm{i}-\mathrm{C}_{4} \mathrm{H}_{3}$ channel, being $50.8 \mathrm{kcal} / \mathrm{mol}$ higher in energy than phenyl $+\mathrm{H}$, is a phenyl decomposition channel in F1. There is a need for clarity as to the actual rates and branching ratios of these unsaturated radical-radical combinations which can undergo multiple rearrangements, especially considering some of the possible new pathways presented here.

\section{ACKNOWLEDGEMENTS}


This work is sponsored by the Department of Energy, Office of Basic Energy Sciences, Division of Chemical Sciences. The authors also thank Henning Richter (M.I.T.) and Nick Marinov (LLNL) for providing electronic copies of their reaction sets and thermochemical properties, Burak Atakan (U. Bielefeld) and Phil Westmoreland (U. Mass. - Amherst) for machine-readable tables of their experimental data, Fran Rupley (Sandia - Livermore) for assistance with the calculations, and Askar Fahr (NIST), Klaus Homann (TH - Darmstadt), John Kiefer (U. of Illinois - Chicago) and Stephen Klippenstein (Cleveland State) for helpful discussions. 


\section{REFERENCES}

[1] Westmoreland, P.R.; Dean, A.M.; Howard, J.B.; Longwell, J.P., J.Phys.Chem., 93:8171-8180 (1989).

[2] Melius, C.F.; Miller, J.A.; Evleth, E.M., Twenty-Fourth Symposium (International) on Combustion, The Combustion Institute, Pittsburgh, 1992, pp. 621-628.

[3] Frenklach, M.; Clary, D.W.; Gardiner, W.C., Jr.; Stein, S.E., Twentieth Symposium (International) on Combustion, The Combustion Institute, Pittsburgh, 1984, pp. 887-901.

[4] Cole, J.A.; Bittner, J.D.; Longwell, J.P.; Hơward, J.B., Combust.Flame, 56:51-70 (1984).

[5] Miller, J.A.; Melius, C.F., Combust.Flame, 91:21-39 (1992).

[6] Pauwels, J.-F., Volponi, J.V., and Miller, J.A., Combust.Sci.Tech., 110-111:249-276 (1995).

[7] Fahr, A.; Laufer, A.; Klein, R.; Braun, W., J.Phys.Chem., 95:3218-3224 (1991).

[8] Thom, R.P.; Payne, W.A.; Stief, L.J.; Tardy, D.C., J.Phys.Chem., 100:13594-13602 (1996).

[9] Homann, K.-H., personal communication.

[10] Wang, H.; Frenklach, M., J.Phys.Chem., 98:11465-11489 (1994).

[11] Marinov, N.M., Pitz, W.J., Westbrook, C.K., Lutz, A.E., Vincitore, A.M., and

Senkan, S.M., Twenty-Seventh Symposium (International) on Combustion, The Combustion Institute, Pittsburgh, 1998, pp. 605-613.

[12] Marinov, N.M., personal communication.

[13] Tsang, W.; Hampson, R.F., J.Phys.Chem.Ref.Data., 15:1087-1279 (1986). 
[14] Marinov, N.M.; Castaldi, M.J.; Melius, C.F.; Tsang, W., Combust.Sci.Tech., 128:295-342 (1997).

[15] Yu, T.; Lin, M.C.; Melius, C.F., IJCK, 26:1095-1104 (1994).

[16] Richter, H., Grieco, W.J., and Howard, J.B., Combust.Flame, 119:1-22 (1999).

[17] Mebel, A.M.; Lin, S.H.; Yang, X.M.; Lee, Y.T., J.Phys.Chem., 101:6781-678 (1997).

[18] Bittner, J.D.; Howard, J.B., Eighteenth Symposium (International) on Combustion, The Combustion Institute, Pittsburgh, 1981, pp. 1105-1116.

[19] Miller, J.A, Twenty-Sixth Symposium (International) on Combustion, The Combustion Institute, Pittsburgh, 1996, pp. 461-480.

[20] Lindstedt, R.P.; Skevis, G., Twenty-Sixth Symposium (International) on Combustion, The Combustion Institute, Pittsburgh, 1996, pp. 703-709.

[21] Moskaleva, L.V.; Mebel, A.M.; Lin, M.C., Twenty-Sixth Symposium (International) on Combustion, The Combustion Institute, Pittsburgh, 1996, pp. 521-526. [22] Walch, S.P., J.Chem.Phys., 103:8544-8547 (1995).

[23] Douté, C.; Delfau, J.-L.; Vovelle, C. Combust.Sci.Tech., 103:153-173 (1994).

[24] Bhargava, A.; Westmoreland, P.R., Combust.Flame, 113:333-347 (1998).

[25] Atakan, B.; Hartlieb, A.T.; Brand, J.; Kohse-Höinghaus, K. Twenty-Seventh Symposium (International) on Combustion, The Combustion Institute, Pittsburgh, 1998, pp. 435-444.

[26] Kee, R.J., Rupley, F.M., and Miller, J.A., Sandia Technical Report SAND89-8009, Sandia National Laboratories, Livermore, CA, December 1989. 
[27] Kee, R.J., Dixon-Lewis, G., Warnatz, J., Coltrin, M.E., and Miller, J.A., Sandia Technical Report SAND86-8246, Sandia National Laboratories, Livermore, CA, December 1990.

[28] Kee, R.J., Grcar, J.F., Smooke, M.D., and Miller, J.A., Sandia Technical Report SAND85-8240, Sandia National Laboratories, Livermore, CA, December 1985.

[29] Grcar, J.F., Kee, R.J., Smooke, M.D., and Miller, J.A., Twenty-First Symposium (International) on Combustion, The Combustion Institute, Pittsburgh, 1991, pp. 17731782.

[30] Kee, R.J., Rupley, F.M., and Miller, J.A., Sandia Technical Report SAND 878215B, Sandia National Laboratories, Livermore, CA, December 1990.

[31] Zhang, H.-Y.; McKinnon, J.T., Combustion and Flame, 107:261-300 (1995).

[32] Guadagnini, R.; Schatz, G.C.; Walch, S.P., J.Phys.Chem.A, 102:5857-5866 (1998).

[33] Bauschlicher, C.W.; Langhoff, S.R., Chem.Phys.Lett., 193:380-385 (1992).

[34] Kiefer, J.H., personal communication.

[35] Alkemade, U.; Homann, K.H., Z.Phys.Chem. (Neue Folge), 161:19-34 (1989).

[36] Morter, C.L.; Farhat, S.K.; Adamson, J.D.; Glass, G.P.; Curl, R.F., J.Phys.Chem., 98:7029-7035 (1994).

[37] Atkinson, D.B.; Hudgens, J.W., J.Phys.Chem.A., 103:4242-4252 (1999).

[38] Fahr, A., personal communication.

[39] Miller, J.A.; Klippenstein, S.J., personal communication.

[40] Wang, F.; Frenklach, M. Combust.Flame, 110:173-221 (1997). 
[41] Castaldi, M.J.; Marinov, N.M.; Melius, C.F.; Huang, J.; Senkan, S.M.; Pitz, W.J.; Westbrook, C.K., Twenty-Sixth Symposium (International) on Combustion, The Combustion Institute, Pittsburgh, 1996, pp. 693-702.

[42] D’Anna, A.; Violi, A., Twenty-Seventh Symposium (International) on Combustion, The Combustion Institute, Pittsburgh, 1998, pp. 423-433. 
Table 1. Rate coefficients for reactions which are discussed in the text and in subsequent figures, and which are used in the expanded mechanism called M1a later in the text. Units are $\mathrm{cm}^{3}$, mol, $\mathrm{s}, \mathrm{kcal}$. pw=present work.

number reaction

$132 \mathrm{C} 2 \mathrm{H} 4+\mathrm{H}=\mathrm{C} 2 \mathrm{H} 3+\mathrm{H} 2$

$154 \quad \mathrm{C} 2 \mathrm{H} 2+\mathrm{O}=\mathrm{HCCO}+\mathrm{H}$

$156 \quad \mathrm{H}+\mathrm{C} 2 \mathrm{H} 2(+\mathrm{M})=\mathrm{C} 2 \mathrm{H} 3(+\mathrm{M})$

Low pressure limit:

TROE centering:

Enhanced third body efficiencies:

$\mathrm{H} 2=2.0, \mathrm{CO}=2.0, \mathrm{CO} 2=3.0, \mathrm{H} 2 \mathrm{O}=5.0$

$157 \mathrm{C} 2 \mathrm{H} 3+\mathrm{H}=\mathrm{C} 2 \mathrm{H} 2+\mathrm{H} 2$

$169 \mathrm{C} 2 \mathrm{H} 3+\mathrm{C} 2 \mathrm{H} 3=\mathrm{CH} 2 \mathrm{CHCCH} 2+\mathrm{H}$

$170 \mathrm{C} 2 \mathrm{H} 3+\mathrm{C} 2 \mathrm{H} 3=\mathrm{H} 2 \mathrm{CCCH}+\mathrm{CH} 3$

$171 \mathrm{C} 2 \mathrm{H} 3+\mathrm{C} 2 \mathrm{H} 3=\mathrm{C} 2 \mathrm{H} 4+\mathrm{C} 2 \mathrm{H} 2$

$225 \mathrm{H}+\mathrm{HCCO}=\mathrm{CH} 2(\mathrm{~S})+\mathrm{CO}$

$240 \mathrm{CH} 2(\mathrm{~S})+\mathrm{H} 2=\mathrm{CH} 3+\mathrm{H}$

$243 \mathrm{CH} 2(\mathrm{~S})+\mathrm{C} 2 \mathrm{H} 2=\mathrm{H} 2 \mathrm{CCCH}+\mathrm{H}$

$267 \mathrm{C} 3 \mathrm{H} 2+\mathrm{C} 2 \mathrm{H} 2=\mathrm{HCCCHCCH}+\mathrm{H}$

$274 \mathrm{H} 2 \mathrm{CCCH}+\mathrm{H}=\mathrm{C} 3 \mathrm{H} 2+\mathrm{H} 2$

$275 \mathrm{H} 2 \mathrm{CCCH}+\mathrm{OH}=\mathrm{C} 3 \mathrm{H} 2+\mathrm{H} 2 \mathrm{O}$

$292 \mathrm{C} 6 \mathrm{H} 6+\mathrm{H}=\mathrm{C} 6 \mathrm{H} 5+\mathrm{H}_{2}$

$296 \mathrm{C} 2 \mathrm{H} 2+\mathrm{CH} 2 \mathrm{CHCHCH}=\mathrm{C} 6 \mathrm{H} 6+\mathrm{H}$

$297 \mathrm{HCCHCCH}+\mathrm{C} 2 \mathrm{H} 2=\mathrm{C} 6 \mathrm{H} 5$

$299 \mathrm{C} 3 \mathrm{H} 4+\mathrm{H}=\mathrm{H} 2 \mathrm{CCCH}+\mathrm{H} 2$

$300 \mathrm{C} 3 \mathrm{H} 4+\mathrm{OH}=\mathrm{H} 2 \mathrm{CCCH}+\mathrm{H} 2 \mathrm{O}$

$302 \mathrm{C} 3 \mathrm{H} 4 \mathrm{P}+\mathrm{H}=\mathrm{CH} 3+\mathrm{C} 2 \mathrm{H} 2$

$306 \quad \mathrm{C} 6 \mathrm{H} 5+\mathrm{O} 2=\mathrm{C} 6 \mathrm{H} 5 \mathrm{O}+\mathrm{O}$

Duplicate of 307

$307 \quad \mathrm{C} 6 \mathrm{H} 5+\mathrm{O} 2=\mathrm{C} 6 \mathrm{H} 5 \mathrm{O}+\mathrm{O}$

Duplicate of 306

$308 \mathrm{C} 6 \mathrm{H} 5 \mathrm{O}=\mathrm{C} 5 \mathrm{H} 5+\mathrm{CO}$

$309 \mathrm{CH} 2+\mathrm{C} 4 \mathrm{H} 2=\mathrm{H} 2 \mathrm{CCCCCH}+\mathrm{H}$

$310 \mathrm{CH}+\mathrm{C} 4 \mathrm{H} 2=\mathrm{C} 5 \mathrm{H} 2+\mathrm{H}$

$311 \mathrm{CH} 2(\mathrm{~S})+\mathrm{C} 4 \mathrm{H} 2=\mathrm{H} 2 \mathrm{CCCCCH}+\mathrm{H}$

$315 \mathrm{C} 4 \mathrm{H}+\mathrm{O} 2=\mathrm{CO}+\mathrm{CO}+\mathrm{C} 2 \mathrm{H}$

$$
\text { A }
$$

$\begin{array}{ll}5.42 \mathrm{E}+14 & 0.0 \\ 1.43 \mathrm{E}+07 & 2.0 \\ 3.114 \mathrm{E}+11 & 0.58 \\ 2.254 \mathrm{E}+40 & -7.269\end{array}$

$\mathrm{a}=0.5, \mathrm{~T}^{* * *}=675.0, \mathrm{~T}^{*}=675$.

$4.00 \mathrm{E}+13$

$9.00 \mathrm{E}+12$

$1.80 \mathrm{E}+13$

$6.30 \mathrm{E}+13$

$1.00 \mathrm{E}+14$

$7.00 \mathrm{E}+13$

$1.80 \mathrm{E}+14$

$5.00 \mathrm{E}+12$

$5.00 \mathrm{E}+13$

$2.00 \mathrm{E}+13$

$3.00 \mathrm{E}+07$

8.209E+08

$1.667 \mathrm{E}+10$

$3.00 \mathrm{E}+07$

$2.00 \mathrm{E}+07$

$1.00 \mathrm{E}+14$

$2.60 \mathrm{E}+13$

$3.00 \mathrm{E}+13$

$7.40 \mathrm{E}+11$

$1.30 \mathrm{E}+13$

$1.00 \mathrm{E}+14$

$3.00 \mathrm{E}+13$

$1.20 \mathrm{E}+12$
E

$\begin{array}{ll}14902.0 & {[5,6]} \\ 1900.0 & {[5,6]} \\ 2589.0 & {[5,6]}\end{array}$

6577.0

$5,6]$

$[5,6]$

$\begin{array}{lll}=675 . & & \\ & & \\ 0.0 & 0.0 & {[5,6]} \\ 0.0 & 0.0 & {[7,8]} \\ 0.0 & 0.0 & {[7-9]} \\ 0.0 & 0.0 & {[7,8]} \\ 0.0 & 0.0 & {[5,6]} \\ 0.0 & 0.0 & {[5,6]} \\ 0.0 & 0.0 & {[5,6]} \\ 0.0 & 5000.0 & {[5,6]} \\ 0.0 & 1000.0 & {[5,6]} \\ 0.0 & 0.0 & {[5,6]} \\ 2.0 & 8000.0 & {[5,6]} \\ 0.801 & 6348.0 & {[10], \mathrm{pw}} \\ 0.446 & 7719.3 & {[10], \mathrm{pw}} \\ 2.0 & 5000.0 & {[5,6]} \\ 2.0 & 1000.0 & {[5,6]} \\ 0.0 & 4000.0 & {[5,6]} \\ 0.0 & 6120.0 & {[5,6]} \\ & & \\ 0.0 & 8981.0 & {[5,6]} \\ 0.0 & & \\ 0.0 & 43853.0 & {[5,6]} \\ 0.0 & 4326.0 & {[5,6]} \\ 0.0 & 0.0 & {[5,6]} \\ 0.0 & 0.0 & {[5,6]} \\ & 0.0 & \mathrm{pw} \\ & & \end{array}$

reference 


\begin{tabular}{|c|c|c|c|c|c|}
\hline 333 & $\mathrm{H}+\mathrm{C} 6 \mathrm{H} 5=\mathrm{C} 6 \mathrm{H} 6$ & $5.00 \mathrm{E}+13$ & 0.0 & 0.0 & {$[5,6]$} \\
\hline 337 & $\mathrm{CH} 2(\mathrm{~S})+\mathrm{C} 2 \mathrm{H} 4=\mathrm{CH} 2 \mathrm{CHCH} 2+\mathrm{H}$ & $1.30 \mathrm{E}+14$ & 0.0 & 0.0 & {$[11,12]$} \\
\hline 338 & $\mathrm{C} 2 \mathrm{H} 3+\mathrm{CH} 3=\mathrm{CH} 2 \mathrm{CHCH} 2+\mathrm{H}$ & $2.861 \mathrm{E}+21$ & -2.118 & 11841.8 & [13] \\
\hline 339 & $\mathrm{C} 2 \mathrm{H} 3+\mathrm{CH} 3=\mathrm{C} 3 \mathrm{H} 6$ & $3.688 \mathrm{E}+30$ & -5.034 & 7691.9 & {$[13]$} \\
\hline 353 & $\mathrm{C} 3 \mathrm{H} 6+\mathrm{H}=\mathrm{C} 2 \mathrm{H} 4+\mathrm{CH} 3$ & $7.23 \mathrm{E}+12$ & 0.0 & 1302.0 & {$[11,12]$} \\
\hline 368 & $\mathrm{CH} 2 \mathrm{CHCH} 2+\mathrm{H}=\mathrm{C} 3 \mathrm{H} 4+\mathrm{H} 2$ & $5.00 \mathrm{E}+13$ & 0.0 & 0.0 & {$[11,12]$} \\
\hline 369 & $\mathrm{CH} 2 \mathrm{CHCH} 2+\mathrm{H}=\mathrm{C} 3 \mathrm{H} 6$ & $1.88 \mathrm{E}+26$ & -3.6 & 5468.0 & {$[11,12]$} \\
\hline 406 & $\mathrm{C} 3 \mathrm{H} 2+\mathrm{H}=\mathrm{C} 3 \mathrm{H}+\mathrm{H} 2$ & $1.00 \mathrm{E}+13$ & 0.0 & 0.0 & pw \\
\hline 407 & $\mathrm{C} 3 \mathrm{H}+\mathrm{O} 2=\mathrm{HCCO}+\mathrm{CO}$ & $1.00 \mathrm{E}+13$ & 0.0 & 0.0 & pw \\
\hline 408 & $\mathrm{C} 3 \mathrm{H}+\mathrm{O}=\mathrm{C} 2 \mathrm{H}+\mathrm{CO}$ & $1.00 \mathrm{E}+13$ & 0.0 & 0.0 & pw \\
\hline 409 & $\mathrm{H} 2 \mathrm{CCCCCH}+\mathrm{H}=\mathrm{C} 5 \mathrm{H} 2+\mathrm{H} 2$ & $1.00 \mathrm{E}+13$ & 0.0 & 0.0 & pw \\
\hline 410 & $\mathrm{HCCCHCCH}+\mathrm{H}=\mathrm{C} 5 \mathrm{H} 2+\mathrm{H} 2$ & $1.00 \mathrm{E}+13$ & 0.0 & 0.0 & pw \\
\hline 411 & $\mathrm{HCCCHCCH}+\mathrm{H}=\mathrm{H} 2 \mathrm{CCCCCH}+\mathrm{H}$ & $1.00 \mathrm{E}+13$ & 0.0 & 0.0 & pw \\
\hline 412 & $\mathrm{H} 2 \mathrm{CCCH}+\mathrm{H} 2 \mathrm{CCCH}=\mathrm{C} 6 \mathrm{H} 5+\mathrm{H}$ & $5.00 \mathrm{E}+12$ & 0.0 & 0.0 & pw \\
\hline 413 & $\mathrm{H} 2 \mathrm{CCCH}+\mathrm{H} 2 \mathrm{CCCH}=\mathrm{FULVENE}$ & $4.50 \mathrm{E}+12$ & 0.0 & 0.0 & pw \\
\hline 414 & $\mathrm{H} 2 \mathrm{CCCH}+\mathrm{H} 2 \mathrm{CCCH}=\mathrm{HCCCHCCH}+\mathrm{CH} 3$ & $5.00 \mathrm{E}+11$ & 0.0 & 0.0 & pw \\
\hline 415 & FULVENE=C6H6 & $7.586 \mathrm{E}+13$ & 0.0 & 73853.0 & {$[2]$} \\
\hline 416 & $\mathrm{H} 2 \mathrm{CCCH}+\mathrm{CH} 2 \mathrm{CHCH} 2=\mathrm{FULVENE}+\mathrm{H}+\mathrm{H}$ & $5.562 \mathrm{E}+20$ & -2.535 & 1692.0 & [14] \\
\hline 417 & $\mathrm{C} 6 \mathrm{H} 5+\mathrm{C} 2 \mathrm{H} 2=\mathrm{C} 6 \mathrm{H} 5 \mathrm{C} 2 \mathrm{H}+\mathrm{H}$ & $2.469 \mathrm{E}+06$ & 1.77 & 2289.0 & [15] \\
\hline 418 & FULVENE+H=C6H6+H & $3.00 \mathrm{E}+12$ & 0.5 & 2000.0 & [14] \\
\hline 483 & $\mathrm{C} 6 \mathrm{H} 5+\mathrm{C} 4 \mathrm{H} 2=\mathrm{C} 6 \mathrm{H} 5 \mathrm{C} 2 \mathrm{H}+\mathrm{C} 2 \mathrm{H}$ & $2.00 \mathrm{E}+13$ & 0.0 & 0.0 & [16] \\
\hline 487 & $\mathrm{C} 6 \mathrm{H} 5+\mathrm{CH} 3=\mathrm{C} 7 \mathrm{H} 8$ & $2.00 \mathrm{E} 22$ & -3.045 & 2304.0 & [16] \\
\hline 501 & $\mathrm{C} 6 \mathrm{H} 5+\mathrm{CH} 3=\mathrm{C} 7 \mathrm{H} 7+\mathrm{H}$ & $5.00 \mathrm{E}+13$ & 0.0 & 0.0 & [16] \\
\hline 506 & $\mathrm{HCCHCCH}+\mathrm{C} 2 \mathrm{H} 3=\mathrm{FULVENE}$ & $4.00 \mathrm{E}+12$ & 0.0 & 0.0 & pw \\
\hline 507 & $\mathrm{HCCHCCH}+\mathrm{C} 2 \mathrm{H} 3=\mathrm{C} 6 \mathrm{H} 5+\mathrm{H}$ & $1.60 \mathrm{E}+13$ & 0.0 & 0.0 & pw \\
\hline 508 & $\mathrm{HCCHCCH}+\mathrm{C} 2 \mathrm{H} 3=\mathrm{C} 4 \mathrm{H} 2+\mathrm{C} 2 \mathrm{H} 4$ & $1.00 \mathrm{E}+12$ & 0.0 & 5000.0 & pw \\
\hline 509 & $\mathrm{HCCHCCH}+\mathrm{C} 2 \mathrm{H} 3=\mathrm{CH} 2 \mathrm{CHCCH}+\mathrm{C} 2 \mathrm{H} 2$ & $2.00 \mathrm{E}+12$ & 0.0 & 5000.0 & pw \\
\hline 510 & $\mathrm{CH} 2 \mathrm{CHCHCH}+\mathrm{C} 2 \mathrm{H}=\mathrm{FULVENE}$ & $4.00 \mathrm{E}+12$ & 0.0 & 0.0 & pw \\
\hline 511 & $\mathrm{CH} 2 \mathrm{CHCHCH}+\mathrm{C} 2 \mathrm{H}=\mathrm{C} 6 \mathrm{H} 5+\mathrm{H}$ & $1.60 \mathrm{E}+13$ & 0.0 & 0.0 & pw \\
\hline 512 & $\mathrm{CH} 2 \mathrm{CHCHCH}+\mathrm{C} 2 \mathrm{H}=\mathrm{CH} 2 \mathrm{CHCCH}+\mathrm{C} 2 \mathrm{H} 2$ & $3.00 \mathrm{E}+12$ & 0.0 & 5000.0 & pw \\
\hline 513 & $\mathrm{H} 2 \mathrm{CCCCH}+\mathrm{C} 2 \mathrm{H} 3=\mathrm{FULVENE}$ & $1.00 \mathrm{E}+13$ & 0.0 & 0.0 & pw \\
\hline 514 & $\mathrm{H} 2 \mathrm{CCCCH}+\mathrm{C} 2 \mathrm{H} 3=\mathrm{C} 6 \mathrm{H} 5+\mathrm{H}$ & $6.00 \mathrm{E}+12$ & 0.0 & 0.0 & pw \\
\hline 515 & $\mathrm{H} 2 \mathrm{CCCCH}+\mathrm{C} 2 \mathrm{H} 3=2 \mathrm{H} 2 \mathrm{CCCH}$ & $4.00 \mathrm{E}+12$ & 0.0 & 0.0 & pw \\
\hline 516 & $\mathrm{H} 2 \mathrm{CCCCH}+\mathrm{C} 2 \mathrm{H} 3=\mathrm{C} 4 \mathrm{H} 2+\mathrm{C} 2 \mathrm{H} 4$ & $1.00 \mathrm{E}+12$ & 0.0 & 5000.0 & pw \\
\hline 517 & $\mathrm{H} 2 \mathrm{CCCCH}+\mathrm{C} 2 \mathrm{H} 3=\mathrm{CH} 2 \mathrm{CHCCH}+\mathrm{C} 2 \mathrm{H} 2$ & $2.00 \mathrm{E}+12$ & 0.0 & 5000.0 & pw \\
\hline 518 & $\mathrm{CH} 2 \mathrm{CHCCH} 2+\mathrm{C} 2 \mathrm{H}=\mathrm{FULVENE}$ & $1.00 \mathrm{E}+13$ & 0.0 & 0.0 & pw \\
\hline 519 & $\mathrm{CH} 2 \mathrm{CHCCH} 2+\mathrm{C} 2 \mathrm{H}=\mathrm{C} 6 \mathrm{H} 5+\mathrm{H}$ & $6.00 \mathrm{E}+12$ & 0.0 & 0.0 & pw \\
\hline
\end{tabular}


$520 \mathrm{CH} 2 \mathrm{CHCCH} 2+\mathrm{C} 2 \mathrm{H}=2 \mathrm{H} 2 \mathrm{CCCH}$

$521 \mathrm{CH} 2 \mathrm{CHCCH} 2+\mathrm{C} 2 \mathrm{H}=\mathrm{CH} 2 \mathrm{CHCCH}+\mathrm{C} 2 \mathrm{H} 2$

$522 \mathrm{H} 2 \mathrm{CCCCCH}+\mathrm{CH} 3=$ FULVENE

$523 \mathrm{H} 2 \mathrm{CCCCCH}+\mathrm{CH} 3=\mathrm{C} 6 \mathrm{H} 5+\mathrm{H}$

$524 \mathrm{H} 2 \mathrm{CCCCCH}+\mathrm{CH} 3=\mathrm{C} 5 \mathrm{H} 2+\mathrm{CH} 4$

$525 \mathrm{HCCCHCCH}+\mathrm{CH} 3=\mathrm{FULVENE}$

$526 \mathrm{HCCCHCCH}+\mathrm{CH} 3=\mathrm{C} 6 \mathrm{H} 5+\mathrm{H}$

527
$4.00 \mathrm{E}+12$

$3.00 \mathrm{E}+12$

$1.40 \mathrm{E}+13$

$6.00 \mathrm{E}+12$

$3.00 \mathrm{E}+12$

$1.00 \mathrm{E}+13$

$1.00 \mathrm{E}+13$

$3.00 \mathrm{E}+12$
0.0
0.0
0.0
0.0
0.0
0.0
0.0
0.0

0.0

5000.0

0.0

0.0

5000.0

0.0

0.0

5000.0 pw

pw

[17],pw

[17],pw

pw

[17],pw

[17],pw

pw 
Table 2. Key properties of flames used in the present study. For all flames, $\mathrm{O}_{2}$ is the oxidant and $\mathrm{Ar}$ is the diluent.

\begin{tabular}{|c|c|c|c|c|c|c|c|}
\hline \# & fuel & $\begin{array}{l}\text { inlet equivalence } \\
\text { ratio } \mathrm{C} / \mathrm{O} \text { ratio }\end{array}$ & $\begin{array}{l}\text { inlet } \\
\mathrm{mol} \% \mathrm{Ar}\end{array}$ & $\begin{array}{l}\text { pressure } \\
\text { (Torr) }\end{array}$ & $\begin{array}{l}\text { mass flow } \\
\text { rate }\left(\mathrm{g} / \mathrm{cm}^{2}-\mathrm{s}\right)\end{array}$ & $\begin{array}{l}\text { maximum } \\
\text { Temperature (K) }\end{array}$ & reference \\
\hline 1 & $\mathrm{C}_{2} \mathrm{H}_{2}$ & $2.50,1.000$ & $45 \%$ & 20.0 & $3.55 \mathrm{E}-03$ & 1866 & {$[23]$} \\
\hline$F 2$ & $\mathrm{C}_{2} \mathrm{H}_{4}$ & $1.90,0.633$ & $50 \%$ & 20.0 & $2.37 \mathrm{E}-03$ & 2208 & [24] \\
\hline & $\mathrm{C}_{3} \mathrm{H}_{6}$ & $2.32,0.772$ & $25 \%$ & 37.5 & $3.12 \mathrm{E}-03$ & 2300 & [25] \\
\hline
\end{tabular}


Table 3. Predicted peak mole fractions, for mechanisms, M1, M1a, M2, M3: a) flame F1, b) flame F2, c) flame F3. Modeling results for many species are sums of predicted concentrations of more than one isomer. "xxx" means that no such species is present in that mechanism or that no data are available.

a) $\mathrm{C}_{2} \mathrm{H}_{2}$ flame -- $\mathrm{F} 1$

$\begin{array}{llllll}\text { species } & \text { M1 } & \text { M1a } & \text { M2 } & \text { M3 } & \text { data } \\ \mathrm{H} & 8.36 \mathrm{E}-03 & 7.98 \mathrm{E}-03 & 6.26 \mathrm{E}-03 & 7.35 \mathrm{E}-03 & 1.79 \mathrm{E}-02 \\ \mathrm{H} 2 & 1.15 \mathrm{E}-01 & 9.67 \mathrm{E}-02 & 6.58 \mathrm{E}-02 & 1.05 \mathrm{E}-01 & 1.59 \mathrm{E}-01 \\ \mathrm{CH} 3 & 1.13 \mathrm{E}-03 & 1.31 \mathrm{E}-03 & 1.66 \mathrm{E}-03 & 2.08 \mathrm{E}-03 & 1.63 \mathrm{E}-03 \\ \mathrm{CH} 4 & 7.58 \mathrm{E}-04 & 7.25 \mathrm{E}-04 & 1.20 \mathrm{E}-03 & 1.14 \mathrm{E}-03 & 1.40 \mathrm{E}-03 \\ \mathrm{OH} & 9.98 \mathrm{E}-04 & 1.25 \mathrm{E}-03 & 1.94 \mathrm{E}-03 & 1.08 \mathrm{E}-03 & 4.94 \mathrm{E}-04 \\ \mathrm{H} 2 \mathrm{O} & 8.65 \mathrm{E}-02 & 9.98 \mathrm{E}-02 & 1.23 \mathrm{E}-01 & 9.14 \mathrm{E}-02 & 8.07 \mathrm{E}-02 \\ \mathrm{C} 2 \mathrm{H} & 7.51 \mathrm{E}-05 & 7.02 \mathrm{E}-05 & 3.96 \mathrm{E}-05 & 2.87 \mathrm{E}-05 & 6.36 \mathrm{E}-05 \\ \mathrm{C} 2 \mathrm{H} 3 & 4.78 \mathrm{E}-05 & 4.73 \mathrm{E}-05 & 1.74 \mathrm{E}-05 & 6.66 \mathrm{E}-05 & 3.77 \mathrm{E}-05 \\ \mathrm{C} 2 \mathrm{H} 4 & 1.14 \mathrm{E}-03 & 4.04 \mathrm{E}-04 & 5.34 \mathrm{E}-04 & 1.38 \mathrm{E}-03 & 2.99 \mathrm{E}-04 \\ \mathrm{CO} & 3.36 \mathrm{E}-01 & 3.19 \mathrm{E}-01 & 2.85 \mathrm{E}-01 & 3.27 \mathrm{E}-01 & 3.61 \mathrm{E}-01 \\ \mathrm{HO} 2 & 4.81 \mathrm{E}-04 & 5.49 \mathrm{E}-04 & 6.35 \mathrm{E}-05 & 3.76 \mathrm{E}-04 & 1.93 \mathrm{E}-04 \\ \mathrm{C} 3 \mathrm{H} 3 & 5.63 \mathrm{E}-04 & 5.30 \mathrm{E}-04 & 1.29 \mathrm{E}-02 & 1.89 \mathrm{E}-03 & 2.24 \mathrm{E}-04 \\ \mathrm{C} 3 \mathrm{H} 4 & 9.65 \mathrm{E}-05 & 5.21 \mathrm{E}-05 & 2.63 \mathrm{E}-03 & 2.35 \mathrm{E}-04 & 5.49 \mathrm{E}-04 \\ \mathrm{CO} 2 & 3.28 \mathrm{E}-02 & 3.76 \mathrm{E}-02 & 5.03 \mathrm{E}-02 & 3.69 \mathrm{E}-02 & 3.29 \mathrm{E}-02 \\ \mathrm{C} 4 \mathrm{H} 2 & 1.99 \mathrm{E}-03 & 2.92 \mathrm{E}-03 & 1.21 \mathrm{E}-02 & 7.12 \mathrm{E}-03 & 4.57 \mathrm{E}-03 \\ \mathrm{C} 4 \mathrm{H} 3 & 9.45 \mathrm{E}-05 & 9.21 \mathrm{E}-05 & 3.51 \mathrm{E}-04 & 1.02 \mathrm{E}-04 & 8.76 \mathrm{E}-06 \\ \mathrm{C} 4 \mathrm{H} 4 & 1.24 \mathrm{E}-04 & 1.00 \mathrm{E}-04 & 8.57 \mathrm{E}-04 & 2.58 \mathrm{E}-04 & 2.49 \mathrm{E}-04 \\ \mathrm{C} 4 \mathrm{H} 5 & 1.04 \mathrm{E}-06 & 5.84 \mathrm{E}-06 & 1.60 \mathrm{E}-06 & 6.94 \mathrm{E}-05 & 3.13 \mathrm{E}-05 \\ \mathrm{C} 5 \mathrm{H} 2 & 4.37 \mathrm{E}-05 & 1.79 \mathrm{E}-05 & 5.58 \mathrm{E}-04 & 2.28 \mathrm{E}-04 & \text { xxx } \\ \mathrm{C} 5 \mathrm{H} 3 & 5.06 \mathrm{E}-04 & 2.36 \mathrm{E}-03 & 1.94 \mathrm{E}-03 & 1.11 \mathrm{E}-03 & \text { xxx } \\ \mathrm{C} 6 \mathrm{H} 5 & 2.24 \mathrm{E}-06 & 2.71 \mathrm{E}-06 & 5.23 \mathrm{E}-07 & 1.44 \mathrm{E}-05 & \text { xxx } \\ \mathrm{C} 6 \mathrm{H} 6 & 2.31 \mathrm{E}-05 & 4.93 \mathrm{E}-05 & 4.35 \mathrm{E}-05 & 7.27 \mathrm{E}-04 & 5.87 \mathrm{E}-05\end{array}$

b) $\mathrm{C}_{2} \mathrm{H}_{4}$ flame -- $\mathrm{F} 2$

$\begin{array}{llllll}\text { species } & \text { M1 } & \text { M1a } & \text { M2 } & \text { M3 } & \text { data } \\ \mathrm{H} & 6.67 \mathrm{E}-03 & 6.23 \mathrm{E}-03 & 9.82 \mathrm{E}-03 & 4.06 \mathrm{E}-03 & 1.10 \mathrm{E}-02 \\ \mathrm{H} 2 & 1.48 \mathrm{E}-01 & 1.44 \mathrm{E}-01 & 1.47 \mathrm{E}-01 & 1.33 \mathrm{E}-01 & 1.41 \mathrm{E}-01 \\ \mathrm{CH} 2 & 1.53 \mathrm{E}-04 & 1.78 \mathrm{E}-04 & 2.97 \mathrm{E}-04 & 2.12 \mathrm{E}-04 & 6.31 \mathrm{E}-05 \\ \mathrm{CH} 3 & 1.46 \mathrm{E}-03 & 1.96 \mathrm{E}-03 & 3.01 \mathrm{E}-03 & 2.31 \mathrm{E}-03 & 3.36 \mathrm{E}-03 \\ \mathrm{CH} 4 & 3.19 \mathrm{E}-03 & 4.76 \mathrm{E}-03 & 5.74 \mathrm{E}-03 & 5.38 \mathrm{E}-03 & 4.45 \mathrm{E}-03 \\ \mathrm{OH} & 1.18 \mathrm{E}-03 & 1.19 \mathrm{E}-03 & 1.93 \mathrm{E}-03 & 8.87 \mathrm{E}-04 & 2.17 \mathrm{E}-03 \\ \mathrm{H} 2 \mathrm{O} & 1.71 \mathrm{E}-01 & 1.75 \mathrm{E}-01 & 1.79 \mathrm{E}-01 & 1.78 \mathrm{E}-01 & 1.64 \mathrm{E}-01 \\ \mathrm{C} 2 \mathrm{H} & 2.89 \mathrm{E}-05 & 3.12 \mathrm{E}-05 & 1.62 \mathrm{E}-05 & 1.03 \mathrm{E}-05 & 4.99 \mathrm{E}-05 \\ \mathrm{C} 2 \mathrm{H} 2 & 2.91 \mathrm{E}-02 & 3.01 \mathrm{E}-02 & 2.56 \mathrm{E}-02 & 3.68 \mathrm{E}-02 & 3.33 \mathrm{E}-02 \\ \mathrm{C} 2 \mathrm{H} 3 & 1.08 \mathrm{E}-03 & 9.05 \mathrm{E}-04 & 4.55 \mathrm{E}-04 & 3.85 \mathrm{E}-04 & 6.74 \mathrm{E}-05\end{array}$




$\begin{array}{llllll}\mathrm{CO} & 2.44 \mathrm{E}-01 & 2.42 \mathrm{E}-01 & 2.42 \mathrm{E}-01 & 2.31 \mathrm{E}-01 & 2.49 \mathrm{E}-01 \\ \mathrm{C} 2 \mathrm{H} 5 & 1.44 \mathrm{E}-04 & 1.25 \mathrm{E}-04 & 3.62 \mathrm{E}-04 & 9.87 \mathrm{E}-05 & 1.07 \mathrm{E}-03 \\ \mathrm{CH} 2 \mathrm{O} & 6.16 \mathrm{E}-03 & 5.88 \mathrm{E}-03 & 5.26 \mathrm{E}-03 & 1.64 \mathrm{E}-03 & 4.32 \mathrm{E}-03 \\ \mathrm{C} 3 \mathrm{H} 2 & 4.59 \mathrm{E}-04 & 2.82 \mathrm{E}-04 & 1.04 \mathrm{E}-04 & 7.44 \mathrm{E}-05 & 2.25 \mathrm{E}-04 \\ \mathrm{C} 3 \mathrm{H} 3 & 6.77 \mathrm{E}-04 & 4.96 \mathrm{E}-04 & 2.82 \mathrm{E}-03 & 1.01 \mathrm{E}-03 & 4.26 \mathrm{E}-04 \\ \mathrm{C} 3 \mathrm{H} 4 & 7.21 \mathrm{E}-04 & 5.51 \mathrm{E}-04 & 2.40 \mathrm{E}-04 & 6.32 \mathrm{E}-04 & 7.32 \mathrm{E}-04 \\ \mathrm{C} 3 \mathrm{H} 5 & 6.70 \mathrm{E}-04 & 4.84 \mathrm{E}-04 & 3.24 \mathrm{E}-04 & 1.31 \mathrm{E}-03 & 6.80 \mathrm{E}-05 \\ \mathrm{C} 3 \mathrm{H} 6 & 6.96 \mathrm{E}-04 & 5.96 \mathrm{E}-04 & 1.80 \mathrm{E}-03 & 5.00 \mathrm{E}-03 & 8.40 \mathrm{E}-04 \\ \mathrm{CH} 2 \mathrm{CHO} & 1.10 \mathrm{E}-04 & 1.01 \mathrm{E}-04 & \mathrm{xxx} & 1.32 \mathrm{E}-05 & 3.49 \mathrm{E}-04 \\ \mathrm{CH} 3 \mathrm{CHO} & 4.83 \mathrm{E}-05 & 4.66 \mathrm{E}-05 & \mathrm{xxx} & 8.18 \mathrm{E}-05 & 3.51 \mathrm{E}-04 \\ \mathrm{CO} 2 & 4.56 \mathrm{E}-02 & 4.72 \mathrm{E}-02 & 4.63 \mathrm{E}-02 & 5.05 \mathrm{E}-02 & 5.18 \mathrm{E}-02 \\ \mathrm{C} 4 \mathrm{H} 2 & 4.92 \mathrm{E}-04 & 8.66 \mathrm{E}-04 & 1.70 \mathrm{E}-03 & 2.28 \mathrm{E}-03 & 2.52 \mathrm{E}-03 \\ \mathrm{C} 4 \mathrm{H} 3 & 1.23 \mathrm{E}-04 & 1.40 \mathrm{E}-04 & 6.84 \mathrm{E}-05 & 9.85 \mathrm{E}-05 & 6.70 \mathrm{E}-06 \\ \mathrm{C} 4 \mathrm{H} 4 & 2.92 \mathrm{E}-04 & 3.36 \mathrm{E}-04 & 1.71 \mathrm{E}-04 & 3.56 \mathrm{E}-04 & 1.69 \mathrm{E}-04 \\ \mathrm{C} 4 \mathrm{H} 5 & 2.42 \mathrm{E}-05 & 8.96 \mathrm{E}-05 & 2.79 \mathrm{E}-05 & 3.18 \mathrm{E}-04 & 2.90 \mathrm{E}-06 \\ \mathrm{C} 4 \mathrm{H} 6 & 9.83 \mathrm{E}-05 & 1.02 \mathrm{E}-04 & 1.70 \mathrm{E}-06 & 9.75 \mathrm{E}-05 & 4.63 \mathrm{E}-05 \\ \mathrm{C} 4 \mathrm{H} 7 & \mathrm{xxx} & \mathrm{xxx} & \mathrm{xxx} & 1.27 \mathrm{E}-06 & 2.03 \mathrm{E}-06 \\ \mathrm{C} 4 \mathrm{H} 8 & \mathrm{xxx} & \mathrm{xxx} & \mathrm{xxx} & 5.31 \mathrm{E}-04 & 7.99 \mathrm{E}-05 \\ \mathrm{C} 5 \mathrm{H} 2 & 6.01 \mathrm{E}-06 & 4.80 \mathrm{E}-06 & 6.08 \mathrm{E}-05 & 3.22 \mathrm{E}-05 & \mathrm{xxx} \\ \mathrm{C} 5 \mathrm{H} 3 & 1.23 \mathrm{E}-04 & 2.78 \mathrm{E}-04 & 1.76 \mathrm{E}-04 & 2.34 \mathrm{E}-04 & \mathrm{xxx} \\ \mathrm{C} 5 \mathrm{H} 6 & \mathrm{xxx} & 3.27 \mathrm{E}-06 & 1.28 \mathrm{E}-06 & 8.58 \mathrm{E}-06 & 1.37 \mathrm{E}-05 \\ \mathrm{C} 5 \mathrm{H} 7 & \mathrm{xxx} & \mathrm{xxx} & \mathrm{xxx} & 1.91 \mathrm{E}-08 & 5.45 \mathrm{E}-06 \\ \mathrm{C} 5 \mathrm{H} 8 & \mathrm{xxx} & \mathrm{xxx} & \mathrm{xxx} & 1.90 \mathrm{E}-07 & 7.98 \mathrm{E}-06 \\ \mathrm{C} 6 \mathrm{H} 2 & 9.11 \mathrm{E}-06 & 1.62 \mathrm{E}-05 & 2.22 \mathrm{E}-05 & 6.77 \mathrm{E}-05 & 2.40 \mathrm{E}-04 \\ \mathrm{C} 6 \mathrm{H} 4 & 6.80 \mathrm{E}-05 & 8.11 \mathrm{E}-05 & 3.35 \mathrm{E}-07 & \mathrm{xxx} & 1.78 \mathrm{E}-05 \\ \mathrm{C} 6 \mathrm{H} 5 & 2.08 \mathrm{E}-06 & 2.16 \mathrm{E}-06 & 3.92 \mathrm{E}-07 & 1.62 \mathrm{E}-06 & 1.70 \mathrm{E}-05 \\ \mathrm{C} 6 \mathrm{H} 6 & 9.84 \mathrm{E}-06 & 2.14 \mathrm{E}-05 & 3.54 \mathrm{E}-06 & 1.18 \mathrm{E}-04 & 3.33 \mathrm{E}-05\end{array}$

c) $\mathrm{C}_{3} \mathrm{H}_{6}$ flame -- $\mathrm{F} 3$

$\begin{array}{llllll}\text { species } & \text { M1 } & \text { M1a } & \text { M2 } & \text { M3 } & \text { data } \\ \text { H2 } & 2.75 E-01 & 2.94 \mathrm{E}-01 & 2.91 \mathrm{E}-01 & 2.76 \mathrm{E}-01 & 2.60 \mathrm{E}-01 \\ \mathrm{CH} 2 & 1.92 \mathrm{E}-04 & 2.02 \mathrm{E}-04 & 8.61 \mathrm{E}-04 & 2.58 \mathrm{E}-04 & 8.90 \mathrm{E}-04 \\ \mathrm{CH} 3 & 4.50 \mathrm{E}-03 & 4.64 \mathrm{E}-03 & 6.23 \mathrm{E}-03 & 7.89 \mathrm{E}-03 & 1.01 \mathrm{E}-02 \\ \mathrm{CH} 4 & 1.80 \mathrm{E}-02 & 2.01 \mathrm{E}-02 & 3.05 \mathrm{E}-03 & 2.63 \mathrm{E}-02 & 3.10 \mathrm{E}-02 \\ \mathrm{CO} & 3.65 \mathrm{E}-01 & 3.79 \mathrm{E}-01 & 3.78 \mathrm{E}-01 & 3.70 \mathrm{E}-01 & 4.00 \mathrm{E}-01 \\ \mathrm{HCO} & 1.01 \mathrm{E}-04 & 9.44 \mathrm{E}-05 & 7.26 \mathrm{E}-05 & 9.06 \mathrm{E}-05 & 1.50 \mathrm{E}-04 \\ \mathrm{CH} 2 \mathrm{O} & 4.33 \mathrm{E}-03 & 4.00 \mathrm{E}-03 & 3.55 \mathrm{E}-04 & 1.45 \mathrm{E}-03 & 6.90 \mathrm{E}-04 \\ \mathrm{OH} & 1.21 \mathrm{E}-03 & 9.69 \mathrm{E}-04 & 2.42 \mathrm{E}-03 & 7.48 \mathrm{E}-04 & 5.50 \mathrm{E}-03 \\ \mathrm{H} 2 \mathrm{O} & 1.93 \mathrm{E}-01 & 1.81 \mathrm{E}-01 & 2.41 \mathrm{E}-01 & 1.83 \mathrm{E}-01 & 1.64 \mathrm{E}-01 \\ \mathrm{C} 2 \mathrm{H} 2 & 3.29 \mathrm{E}-02 & 4.62 \mathrm{E}-02 & 5.22 \mathrm{E}-02 & 5.79 \mathrm{E}-02 & 3.69 \mathrm{E}-02 \\ \mathrm{C} 2 \mathrm{H} 3 & 6.70 \mathrm{E}-04 & 6.05 \mathrm{E}-04 & 2.45 \mathrm{E}-04 & 3.01 \mathrm{E}-04 & 2.48 \mathrm{E}-03 \\ \mathrm{C} 2 \mathrm{H} 4 & 1.17 \mathrm{E}-02 & 1.26 \mathrm{E}-02 & 6.30 \mathrm{E}-03 & 1.32 \mathrm{E}-02 & 3.42 \mathrm{E}-02 \\ \mathrm{C} 2 \mathrm{H} 5 & 4.66 \mathrm{E}-05 & 4.18 \mathrm{E}-05 & 1.29 \mathrm{E}-05 & 1.05 \mathrm{E}-05 & 3.30 \mathrm{E}-05 \\ \mathrm{C} 2 \mathrm{H} 6 & 8.80 \mathrm{E}-04 & 8.34 \mathrm{E}-04 & 2.11 \mathrm{E}-04 & 1.70 \mathrm{E}-03 & 1.80 \mathrm{E}-03\end{array}$




\begin{tabular}{|c|c|c|c|c|c|}
\hline $\mathrm{C} 2 \mathrm{H} 2 \mathrm{O}$ & $1.20 \mathrm{E}-03$ & $2.35 \mathrm{E}-03$ & 3.27E-04 & 5.02E-03 & $7.50 \mathrm{E}-04$ \\
\hline $\mathrm{CO} 2$ & $3.86 \mathrm{E}-02$ & $3.44 \mathrm{E}-02$ & $4.48 \mathrm{E}-02$ & $3.92 \mathrm{E}-02$ & $2.14 \mathrm{E}-02$ \\
\hline $\mathrm{C} 3 \mathrm{H} 2$ & $1.37 \mathrm{E}-03$ & 8.36E-04 & $1.60 \mathrm{E}-04$ & $2.66 \mathrm{E}-04$ & $1.90 \mathrm{E}-04$ \\
\hline $\mathrm{C} 3 \mathrm{H} 3$ & $3.95 \mathrm{E}-03$ & $2.46 \mathrm{E}-03$ & 7.77E-03 & $2.88 \mathrm{E}-03$ & $3.09 \mathrm{E}-03$ \\
\hline $\mathrm{C} 3 \mathrm{H} 4$ & $1.46 \mathrm{E}-02$ & $1.64 \mathrm{E}-02$ & $1.93 \mathrm{E}-03$ & $1.03 \mathrm{E}-02$ & $1.01 \mathrm{E}-02$ \\
\hline C3H5 & $1.10 \mathrm{E}-02$ & $1.22 \mathrm{E}-02$ & $3.69 \mathrm{E}-03$ & $1.08 \mathrm{E}-02$ & $3.50 \mathrm{E}-03$ \\
\hline $\mathrm{C} 3 \mathrm{H} 7$ & $\mathrm{xxx}$ & $\mathrm{xxx}$ & $\mathrm{xxx}$ & $1.06 \mathrm{E}-05$ & $3.90 \mathrm{E}-04$ \\
\hline $\mathrm{C} 3 \mathrm{H} 4 \mathrm{O}$ & $\mathrm{xxx}$ & $\mathrm{xxx}$ & $\mathrm{xxx}$ & $4.12 \mathrm{E}-03$ & $3.50 \mathrm{E}-05$ \\
\hline $\mathrm{C} 4 \mathrm{H} 2$ & $1.19 \mathrm{E}-03$ & $2.92 \mathrm{E}-03$ & $4.75 \mathrm{E}-03$ & 4.47E-03 & $5.92 \mathrm{E}-03$ \\
\hline $\mathrm{C} 4 \mathrm{H} 3$ & $6.54 \mathrm{E}-04$ & $9.84 \mathrm{E}-04$ & 2.78E-04 & $3.70 \mathrm{E}-04$ & $1.55 \mathrm{E}-04$ \\
\hline $\mathrm{C} 4 \mathrm{H} 4$ & $1.30 \mathrm{E}-03$ & $1.36 \mathrm{E}-03$ & $3.51 \mathrm{E}-04$ & $9.36 \mathrm{E}-04$ & $1.43 \mathrm{E}-03$ \\
\hline $\mathrm{C} 4 \mathrm{H} 5$ & $1.01 \mathrm{E}-04$ & $5.63 \mathrm{E}-04$ & $1.04 \mathrm{E}-06$ & $1.56 \mathrm{E}-03$ & $1.20 \mathrm{E}-04$ \\
\hline $\mathrm{C} 4 \mathrm{H} 6$ & $1.84 \mathrm{E}-05$ & $2.23 \mathrm{E}-04$ & $6.74 \mathrm{E}-06$ & $9.43 \mathrm{E}-04$ & $1.00 \mathrm{E}-03$ \\
\hline $\mathrm{C} 4 \mathrm{H} 7$ & $\mathrm{XXX}$ & $\mathrm{xxx}$ & $\mathrm{XXX}$ & $1.98 \mathrm{E}-05$ & $1.30 \mathrm{E}-04$ \\
\hline $\mathrm{C} 4 \mathrm{H} 8$ & $\mathrm{xxx}$ & $\mathrm{xxx}$ & $\mathrm{XXX}$ & $2.88 \mathrm{E}-03$ & $1.13 \mathrm{E}-03$ \\
\hline $\mathrm{C} 4 \mathrm{H} 10$ & $\mathrm{xxx}$ & $\mathrm{xxx}$ & $\mathrm{xxx}$ & 2.03E-05 & 4.50E-04 \\
\hline $\mathrm{C} 5 \mathrm{H} 2$ & $1.00 \mathrm{E}-05$ & 6.33E-05 & 2.79E-04 & 2.83E-05 & $\mathrm{xxx}$ \\
\hline C5H3 & $3.00 \mathrm{E}-04$ & $6.66 \mathrm{E}-04$ & 6.09E-04 & 3.63E-04 & $\mathrm{xxx}$ \\
\hline C5H5 & $1.13 \mathrm{E}-02$ & $1.42 \mathrm{E}-03$ & $1.02 \mathrm{E}-06$ & 1.63E-04 & 2.50E-04 \\
\hline C5H6 & $\mathrm{xxx}$ & $3.53 \mathrm{E}-04$ & $2.08 \mathrm{E}-06$ & $1.87 \mathrm{E}-04$ & $6.60 \mathrm{E}-04$ \\
\hline $\mathrm{C} 5 \mathrm{H} 7$ & $\mathrm{xxx}$ & $\mathrm{xxx}$ & $\mathrm{xxx}$ & $1.12 \mathrm{E}-07$ & $1.50 \mathrm{E}-04$ \\
\hline C5H8 & $\mathrm{XxX}$ & $\mathrm{xxx}$ & $\mathrm{xxx}$ & $7.13 \mathrm{E}-07$ & $2.10 \mathrm{E}-04$ \\
\hline $\mathrm{C} 6 \mathrm{H} 2$ & $2.47 \mathrm{E}-05$ & $6.62 \mathrm{E}-05$ & $7.90 \mathrm{E}-05$ & $1.08 \mathrm{E}-04$ & $1.50 \mathrm{E}-03$ \\
\hline C6H4 & 1.70E-03 & $1.22 \mathrm{E}-03$ & $1.90 \mathrm{E}-06$ & $1.00 \mathrm{E}-88$ & $2.12 \mathrm{E}-04$ \\
\hline С6H5 & $1.06 \mathrm{E}-04$ & 7.77E-05 & 1.31E-07 & $2.86 \mathrm{E}-05$ & 7.43E-05 \\
\hline $\mathrm{C} 6 \mathrm{H} 6$ & $6.23 \mathrm{E}-04$ & $2.93 \mathrm{E}-03$ & $1.08 \mathrm{E}-05$ & $3.22 \mathrm{E}-03$ & $1.22 \mathrm{E}-03$ \\
\hline $\mathrm{C} 6 \mathrm{H} 7$ & $\mathrm{xxx}$ & $3.35 \mathrm{E}-08$ & $9.64 \mathrm{E}-09$ & 8.34E-08 & 2.02E-04 \\
\hline C6H8 & $\mathrm{xxx}$ & $1.54 \mathrm{E}-08$ & $1.97 \mathrm{E}-06$ & $5.40 \mathrm{E}-05$ & $1.82 \mathrm{E}-04$ \\
\hline С6H5O & $2.16 \mathrm{E}-04$ & $7.54 \mathrm{E}-05$ & $1.47 \mathrm{E}-07$ & $7.50 \mathrm{E}-06$ & $2.10 \mathrm{E}-05$ \\
\hline С6H6O & $\mathrm{xxx}$ & $5.90 \mathrm{E}-07$ & $2.71 \mathrm{E}-06$ & $3.89 \mathrm{E}-05$ & $3.00 \mathrm{E}-05$ \\
\hline $\mathrm{C} 7 \mathrm{H} 7$ & $\mathrm{xxx}$ & $5.71 \mathrm{E}-05$ & $2.56 \mathrm{E}-08$ & $1.08 \mathrm{E}-05$ & 5.20E-05 \\
\hline C7H8 & $\mathrm{xxx}$ & $1.09 \mathrm{E}-04$ & $6.05 \mathrm{E}-08$ & $4.18 \mathrm{E}-05$ & $6.00 \mathrm{E}-05$ \\
\hline $\mathrm{C} 8 \mathrm{H} 6$ & $1.47 \mathrm{E}-05$ & $1.35 \mathrm{E}-05$ & 7.31E-07 & $1.33 \mathrm{E}-05$ & $5.30 \mathrm{E}-05$ \\
\hline $\mathrm{C} 9 \mathrm{H} 8$ & $\mathrm{XxX}$ & $4.22 \mathrm{E}-05$ & 8.78E-09 & 4.30E-07 & $2.00 \mathrm{E}-05$ \\
\hline $\mathrm{C} 10 \mathrm{H} 8$ & $\mathrm{xxx}$ & 4.92E-05 & $3.90 \mathrm{E}-09$ & $4.28 \mathrm{E}-06$ & $1.30 \mathrm{E}-05$ \\
\hline
\end{tabular}


Table 4. Standard heats of formation (in $\mathrm{kcal} / \mathrm{mol}$ ) of $\mathrm{C}_{6} \mathrm{H}_{6}$ species and selected combinations of molecules with combined empirical formula of $\mathrm{C}_{6} \mathrm{H}_{6}$. Thermodynamic properties are from Miller and Melius [5] and Kee et al. [30] unless otherwise noted.

\begin{tabular}{|c|c|c|}
\hline molecule(s) & $\Delta \mathrm{H}_{\mathrm{f}}^{\circ}(2 \mathrm{~s}$ & $98 \mathrm{~K})$ \\
\hline $\mathrm{n}-\mathrm{C}_{4} \mathrm{H}_{5}+\mathrm{C}_{2} \mathrm{H}$ & 218.7 & \\
\hline $\mathrm{i}-\mathrm{C}_{4} \mathrm{H}_{5}+\mathrm{C}_{2} \mathrm{H}$ & 206.3 & \\
\hline o-benzyne $+2 \mathrm{H}$ & 205.8 & \\
\hline $\mathrm{n}-\mathrm{C}_{4} \mathrm{H}_{3}+\mathrm{C}_{2} \mathrm{H}_{3}$ & 201.0 & \\
\hline $\mathrm{i}-\mathrm{C}_{4} \mathrm{H}_{3}+\mathrm{C}_{2} \mathrm{H}_{3}$ & 182.3 & \\
\hline $\mathrm{C}_{3} \mathrm{H}_{3}+\mathrm{C}_{3} \mathrm{H}_{3}$ & 172.0 & {$[33,34$} \\
\hline $\mathrm{n}-\mathrm{C}_{5} \mathrm{H}_{3}+\mathrm{CH}_{3}$ & 169.9 & \\
\hline $\mathrm{i}-\mathrm{C}_{5} \mathrm{H}_{3}+\mathrm{CH}_{3}$ & 163.1 & \\
\hline $\mathrm{C}_{5} \mathrm{H}_{2}+\mathrm{CH}_{4}$ & 147.3 & \\
\hline phenyl+H & 131.5 & \\
\hline $\mathrm{C}_{4} \mathrm{H}_{2}+\mathrm{C}_{2} \mathrm{H}_{4}$ & 123.8 & \\
\hline $\mathrm{CH} 2 \mathrm{CHCCH}+\mathrm{C}_{2} \mathrm{H}_{2}$ & 123.3 & \\
\hline $\mathrm{HCCCH} 2 \mathrm{CHCCH} 2$ & 104.3 & \\
\hline $\mathrm{CH} 3 \mathrm{CHCCHCCH}$ & 99.7 & \\
\hline $\mathrm{CH} 2 \mathrm{CCHCHCCH} 2$ & 96.5 & \\
\hline $\mathrm{CH} 3 \mathrm{CHCCCCH} 2$ & 93.2 & [17] \\
\hline $\mathrm{CH} 2 \mathrm{CCCHCHCH} 2$ & 85.6 & [17] \\
\hline $\mathrm{CH} 2 \mathrm{C}(\mathrm{CCH}) \mathrm{CHCH} 2$ & 82.4 & \\
\hline $\mathrm{CH} 2 \mathrm{CHCHCHCCH}$ & 80.0 & \\
\hline fulvene & 52.5 & \\
\hline benzene & 19.8 & \\
\hline
\end{tabular}




\section{Figure Captions}

Figure 1. Predictions of $\mathrm{C}_{6} \mathrm{H}_{6}$ species from mechanisms $\mathrm{Ml}$ and Mla compared with data: a) $\mathrm{C}_{2} \mathrm{H}_{2}$ flame (F1), b) $\mathrm{C}_{2} \mathrm{H}_{4}$ flame (F2), c) $\mathrm{C}_{3} \mathrm{H}_{6}$ flame (F3). Circles, data; dashed line, benzene from M1; open squares, benzene from M1a; open triangles, fulvene from M1a; solid line, total $\mathrm{C}_{6} \mathrm{H}_{6}$ from M1a.

Figure 2. Predicted major reaction pathways involving phenyl, benzene, and fulvene for the three flames from mechanism M1a. Notations such as \#297 mean that the arrow indicates the reaction so numbered in Table 3 . See text for discussion.

Figure 3. Predicted primary and secondary formation pathways of $\mathrm{C}_{3}$ radicals for the three flames from mechanism M1a. Notations such as \#297 mean that the arrow indicates the reaction so numbered in Table 3. See text for discussion. 


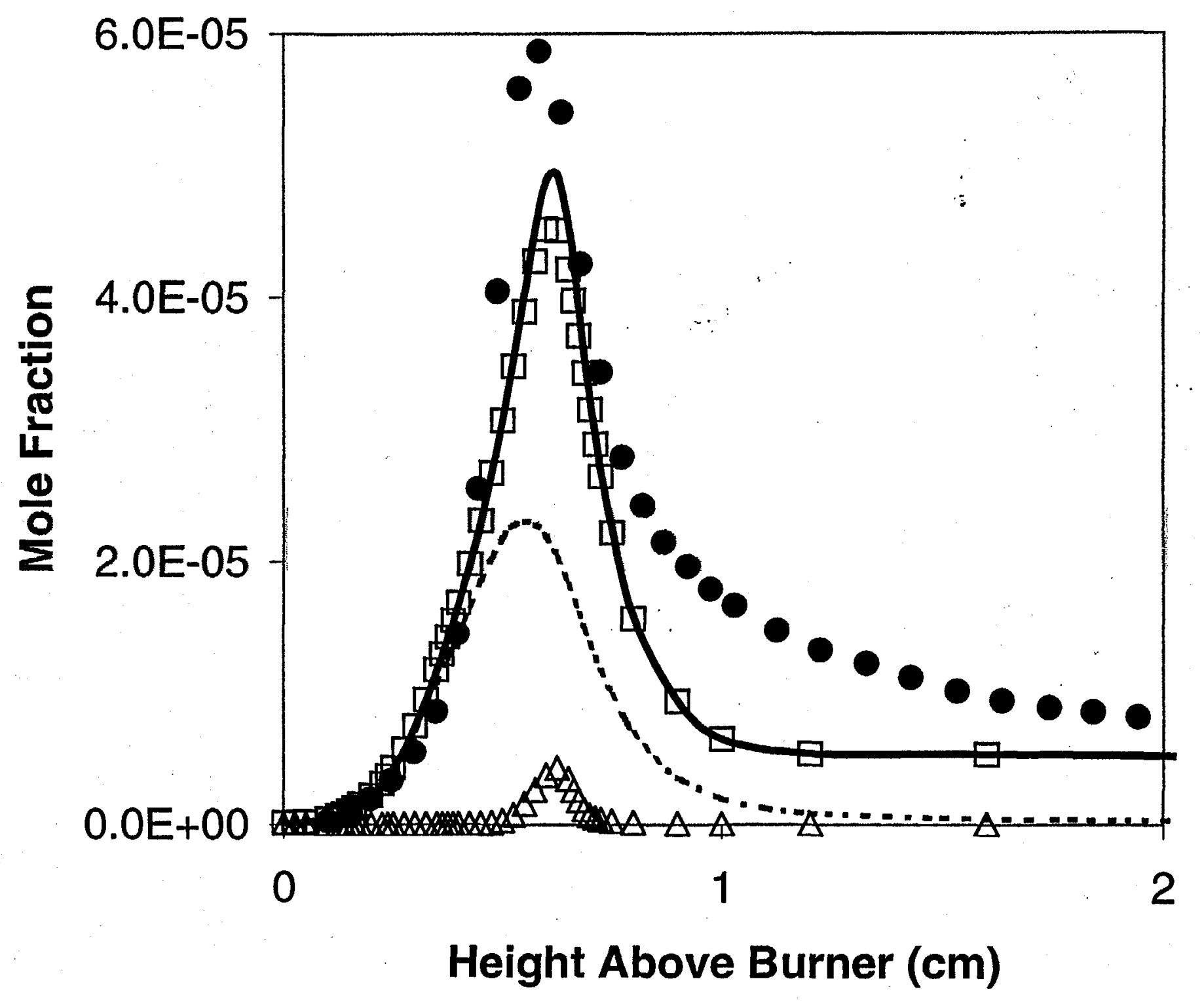

Fig. la 


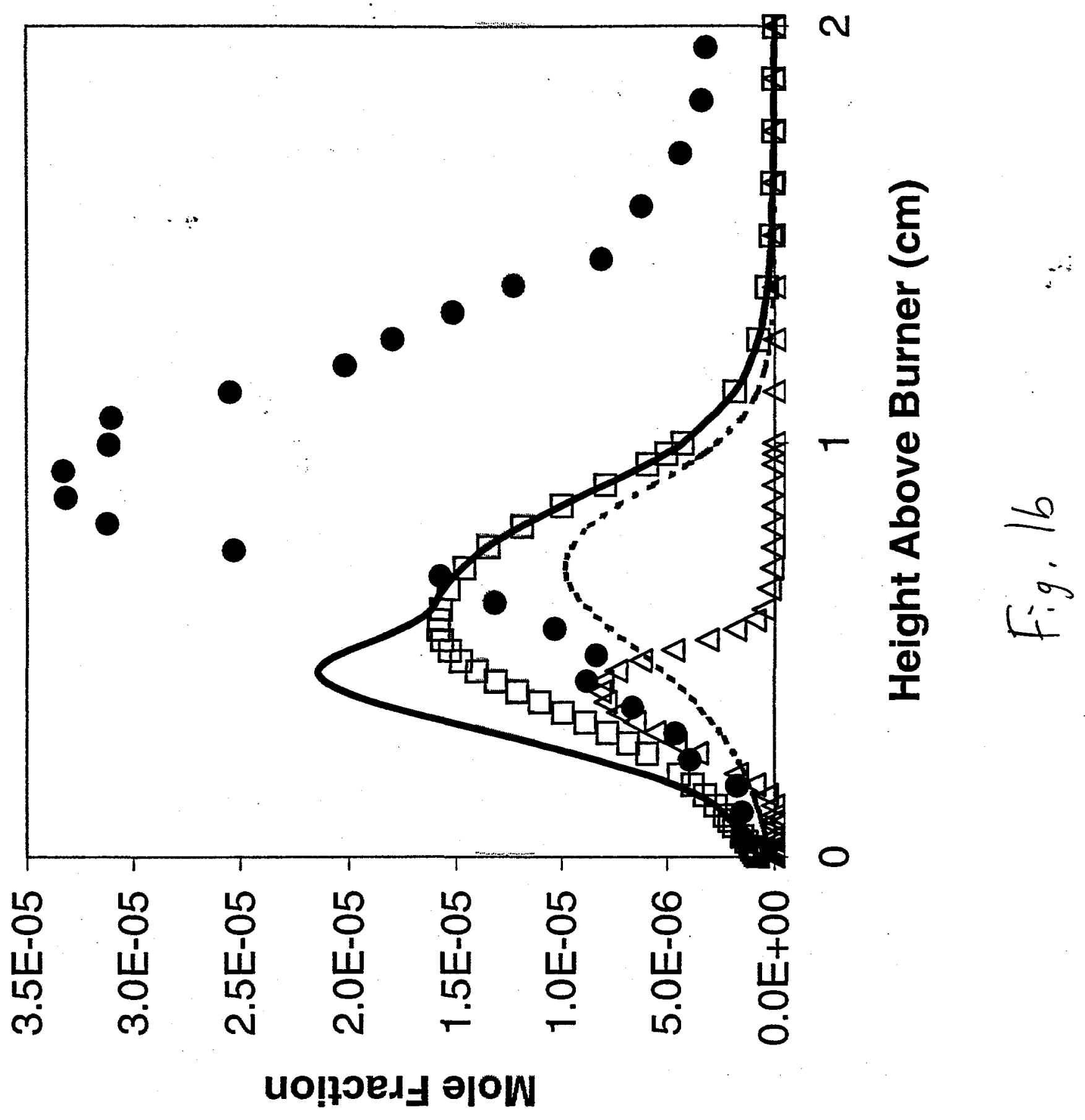




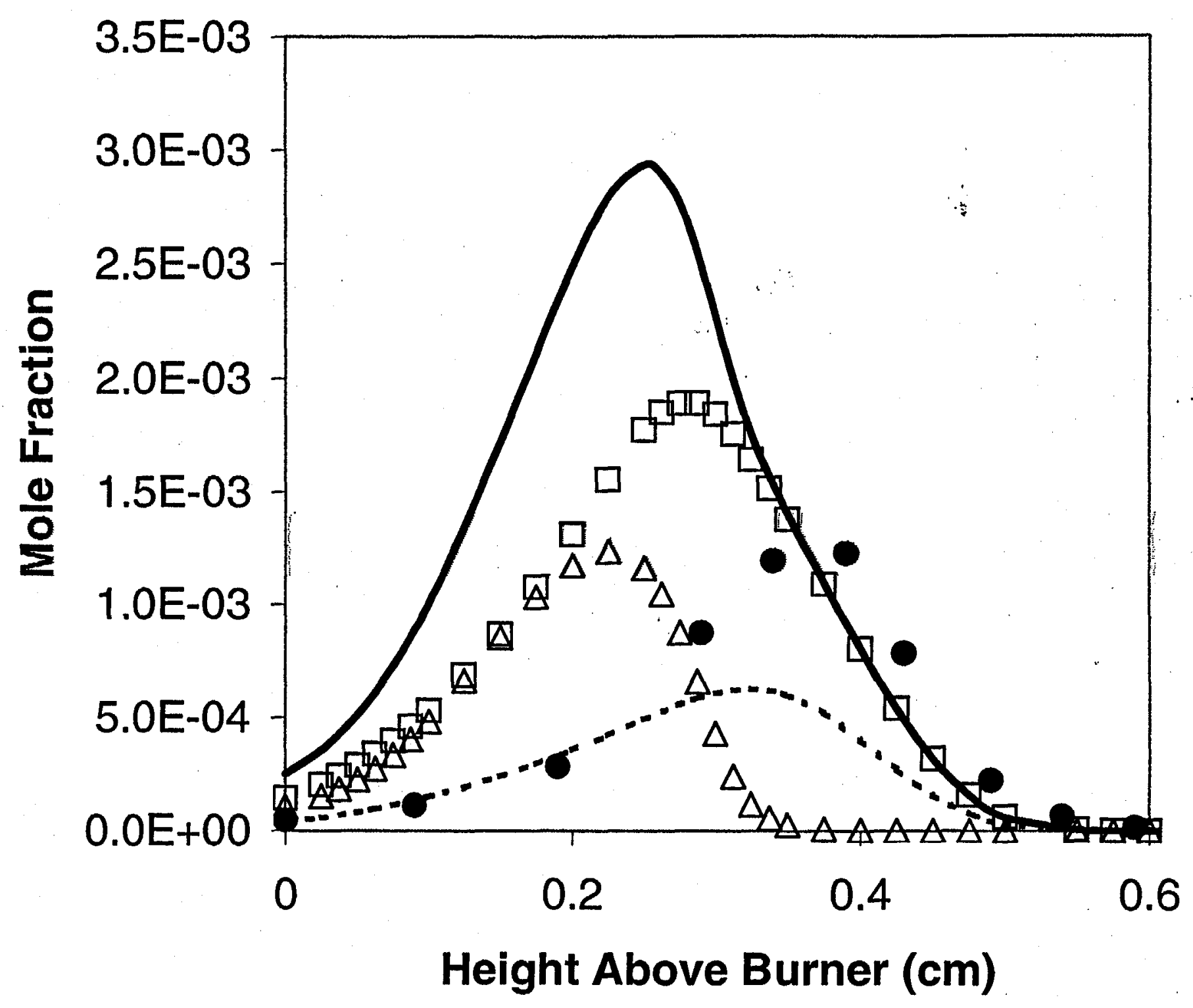

Fig. Io 

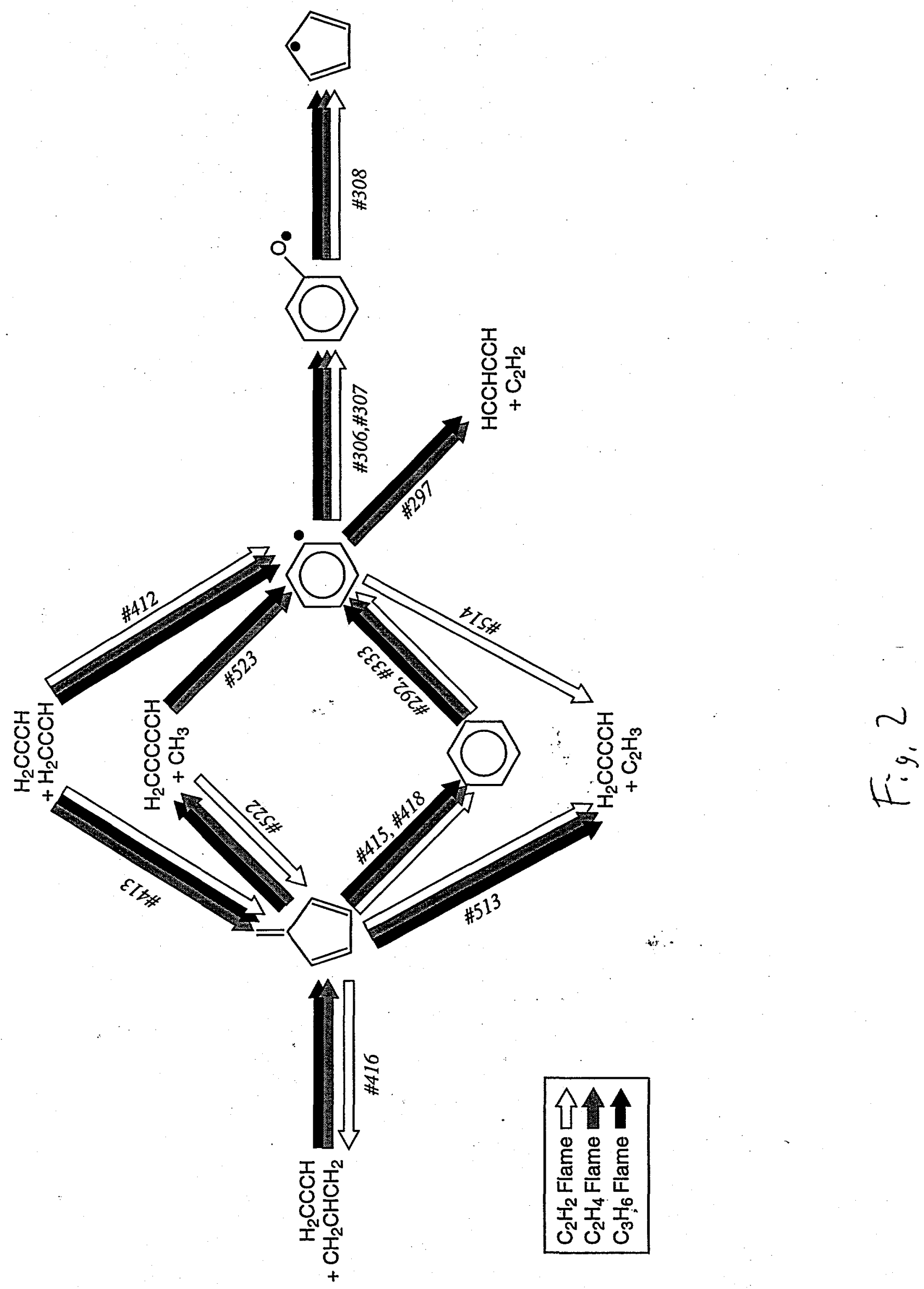


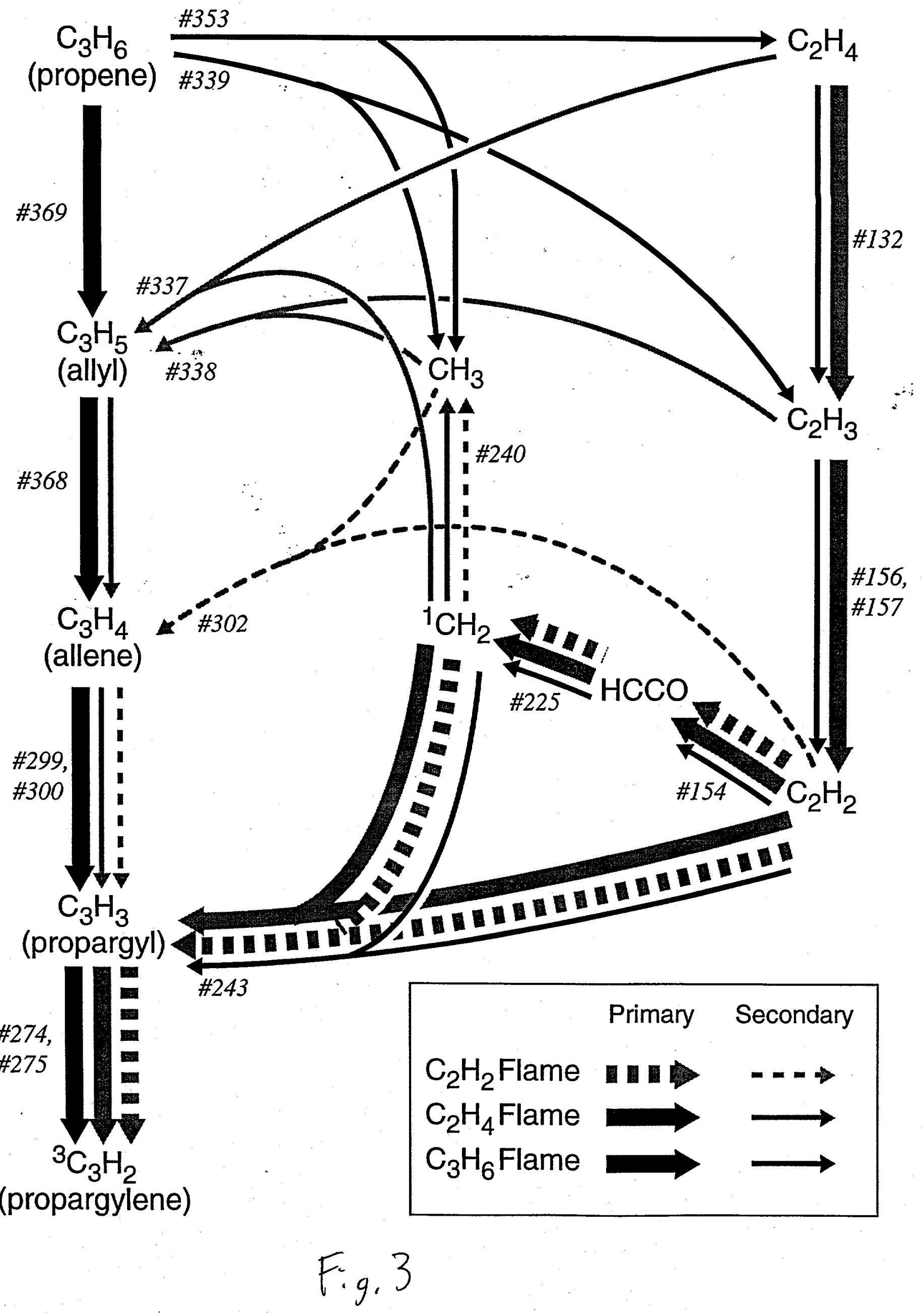

